Article

\title{
A Framework Based on Sustainability, Open Innovation, and Value Cocreation Paradigms-A Case in an Italian Maritime Cluster
}

\author{
Daniela Rupo $^{1, *}$, Mirko Perano ${ }^{2, *(1)}$, Giovanna Centorrino ${ }^{1}$ and Alfonso Vargas-Sanchez ${ }^{3}$ (D) \\ 1 Department of Economics, University of Messina, 98122 Messina, ME, Italy; gcentorrino@unime.it \\ 2 Department of Management, Reald University College, Vlorë 94100, Albania \\ 3 Management and Marketing Department, University of Huelva, 21002 Huelva, Spain; vargas@uhu.es \\ * Correspondence: drupo@unime.it (D.R.); mperano@asar.edu.al (M.P.); Tel.: +39-090-6764526 (D.R.)
}

Received: 2 February 2018; Accepted: 5 March 2018; Published: 7 March 2018

\begin{abstract}
The paper deals with a case study in an Italian maritime cluster seen through a multiple paradigms framework, based on Sustainability (SUS), Open Innovation (OI), and Value Co-creation (VCc). The proposed theoretical framework helps to interpret a true phenomenon consisting of the design of a new product with a prototype created in a network of multiple actors. The approach adopted stems in part from recent writings in qualitative research methodology and is quite apt in this context considering the qualitative, confirmatory nature of this work. The prototype named "TESEO I" was realized through open innovation aimed at sustainability, not only directed at environmental aspects but synergistically with value cocreation, which emerged from interaction among the actors, while also including social and economic aspects. The work concludes with a discussion of theoretical implications related to the proposed framework and the results that emerged from the case study, with both referring to sustainability, open innovation, and value cocreation.
\end{abstract}

Keywords: sustainability; open innovation; value cocreation; maritime cluster

\section{Introduction}

It is common knowledge that entities create public funding programs (e.g., the European Union in agreement with its countries members) by stimulating the establishment of networks, with the objective of realizing research and innovation activities. An example is the Italian public funding program, the Italian National Operational, Research and Competitiveness Program (PONREC) that aims to achieve sustainable goals (enhance quality of life, improve business competitiveness, and employment of young people) in regional areas [1].

Networks are increasing in importance in many economies throughout the world [2] (p. 418), and this presents an excellent opportunity to access funding (or cofounding) programs to realize research and innovation activities. One of the elements of the success of these projects, i.e., the greater value obtained from the applicability of knowledge, can be found in the relational view theory [3-6] adopted by each actor involved in the network. The relational view can be understood not only as a perspective for understanding the organizations but also as a cultural way able of supporting the setup of a network and the interactions with other actors, as well as of facilitating the vale cocreation.

Value created collaboratively with interactions for mutual exchange shapes processes of value cocreation (VCc) [7]. In the case of networks, interactions between the actors involved stimulate the emergence of value propositions that are "used to connect the firm with its suppliers and customers" [8] (p. 21).

As early as the middle of the last century, it emerged from literature that in innovation management, organizations need external links in the innovation process [9-12]. Chesbrough (2003) 
proposed the open innovation (OI) paradigm, meaning that "valuable ideas can come from inside or outside the company and can go to market from inside or outside the company as well" [13] (p. 43). In this way, the use of different external sources (ideas and knowledge) facilitates collaboration between organizations, entities, customers, suppliers, universities, and research centers in their innovation activities [14,15].

As stated above, public entities provide the opportunity to co-fund innovative projects that require the establishment of partnerships/networks to achieve results in sustainability and competitiveness. This is the case in which one or more actors belonging to the same network may have common goals, such as (1) to seize the opportunity to realize an innovative project that already exists but not implemented; and (2) to seize the opportunity to design and implement a new project that meets the requirements of the demand. In both cases, normally, the major common requirements can be identified as innovation and sustainability of outcomes, and establishment of a partnership/network composed of organizations with entities, social actors, and universities/research centers.

The aim of orienting innovation (using the OI paradigm) towards sustainability through VCc by collaborative interaction with multiple actors and stakeholders' engagement, going beyond company boundaries, deserves in-depth analysis.

The current period represents a key moment in the evolution of sustainability, given the landmark achievement set up by the adoption of the 2030 Agenda [16]. This Agenda, which foresees a shared global vision towards sustainable development for all, considers some sustainable development goals (SDGs) that are necessary in order to achieve environmental protection. Among these, much attention is given to marine protection with the proposal of the so-called "Objective 14": to conserve and sustainably use the oceans, seas, and marine resources for sustainable development. This goal starts from the consideration that increasingly adverse impacts of climate change (including ocean acidification), overfishing, and marine pollution are jeopardizing recent achievements in protecting portions of the world's oceans. In particular, in limiting the impact of human activities related to the sea and coastal areas, it also means considering the marine in all its implications, such as fishing and yachting activities to allow navigation in protected or environmentally sound areas without compromising the ecological balance, while not contributing to pollution (emissions and noise) of the sea and port areas. This environmental aspect in the maritime sector also includes social and economic implications, making the adoption of sustainability, in line with the Triple Bottom Line paradigm [17], particularly fitting in this field.

Traditional energy production systems of marine vessels are mostly based on the use of highly polluting internal combustion engines (diesel), and emissions from the international maritime transport sector account for 3\% of global greenhouse gas (GHG) emissions and $4 \%$ of EU GHG emissions [18]. These environmental effects have stimulated the introduction of energy-efficient and environmentally-friendly energy-generating systems as, without interventions, these emissions are expected to increase significantly.

It is necessary to contribute to the diminution of greenhouse gas emission also through measures that are the most environmentally effective and make the most economic sense. Thus, the need for environmental protection has engendered a growing public consciousness and created an opening for what the European Commission has referred to as Blue Growth [19]. This concept acknowledges Europe's strong maritime heritage and looks to provide guidance and solutions to harness the potential of the seas for jobs and economic growth. Among the several efforts made to achieve a comprehensive international solution, a range of instruments including technical and market-based measures have been elaborated, together with the implementation of a series of international proposals in the marine sector, which are increasingly rigorous in terms of environmental protection.

The aim of this paper is twofold.

Firstly, using a multiple paradigm method, a unique theoretical framework based on sustainability, open innovation, and value co-creation paradigms was drawn up. Interactions between the three paradigms and relevant influences are discussed. 
Secondly, a specific case study using a business case research method [20] is used to read the theoretical framework. The case study selected is TESEO, which is part of a large program co-funded by public entities (European Union, Italian public entities). One of the most significant project scopes is the construction of a prototype of a sustainable fishing vessel, realized using high innovation shared throughout the network established for the project.

The central question investigated in this work is to understand the interactions between three paradigms (Sustainability, Open Innovation, and Value Co-creation) in the value network by using a single case study method.

Adopting a lens of a value network [8] in the field of marine transport, the paper intends to investigate how different partners have given varied support in each phase of the jointly carried out project. The objectives of the value network, conceived as an overall purpose of the partnership, were to develop innovation in the marine sector by the adoption of maritime vessels with high efficiency and low environmental impact, and to improve the marketability of boats powered by hybrid electric engines, thanks to solutions combining efficiency (low costs in both the production and consumption phases) with environmental goals, being thus sustainable in the three dimensions of corporate social responsibility (CSR) (economic, social, and environmental).

The twofold scope of the cooperation was to develop applications to improve efficiency by reducing fuel consumption and to pursue safety maximization for the crew with low levels of irradiated noise. The study of this network offered insight into innovation through knowledge sharing, in a context aimed at finding solutions with regard to energy savings, lower environmental impact, and better labour conditions of health and safety. Cooperation took place in a context of coupled OI in which organizations actively cooperated to co-develop product and process innovations [21] to co-create value $[22,23]$ by using the so-called "Fuzzy Front End" (FFE) [24]. This last is the realist stage of new product development (NDP) process and "begins when an opportunity is first considered worthy of further ideation, exploration, and assessment and ends when a firm decides to invest in the idea, commit significant resources to its development, and launch the project" [25] (pp. 269-270); this also presents one of the greatest opportunities for improving the overall innovation process [26] (p. 46).

The empirical investigation allows for the interpretation of the meta-paradigm in context, highlighting critical features of the interaction among actors. The case study represents a concrete experience that testifies how OI and VCc practices work, and the kind of mutual benefits that can arise, while at the same time producing positive environmental effects and highlighting the virtuous social implications of sound economic behavior.

The paper is organized as follows. Section 2 discusses the theoretical framework based on the multiple paradigms approach; the research methodology, based on the qualitative case study approach, is examined in Section 3, which describes the motivation of the study, the data setting, and the data analysis. The results of the study are presented in Section 3.2, while Section 4 outlines the discussion addressing the research aim. Section 5 draws conclusions and examines limitations and the further direction of the study.

\section{Theoretical Framework}

A theoretical framework based on multiple paradigms of Sustainability (SUS) [17] Open Innovation (OI) [13] and Value Cocreation (VCc) [23] is provided (Figure 1). The multiple paradigm approach "stems at least partially from recent writings in qualitative research methodology" [27] (p. 23) and is very apt in this context considering the qualitative nature of the work. Under the holistic perspective, different but integrated viewing angles help one to better comprehend the observed phenomenon. 


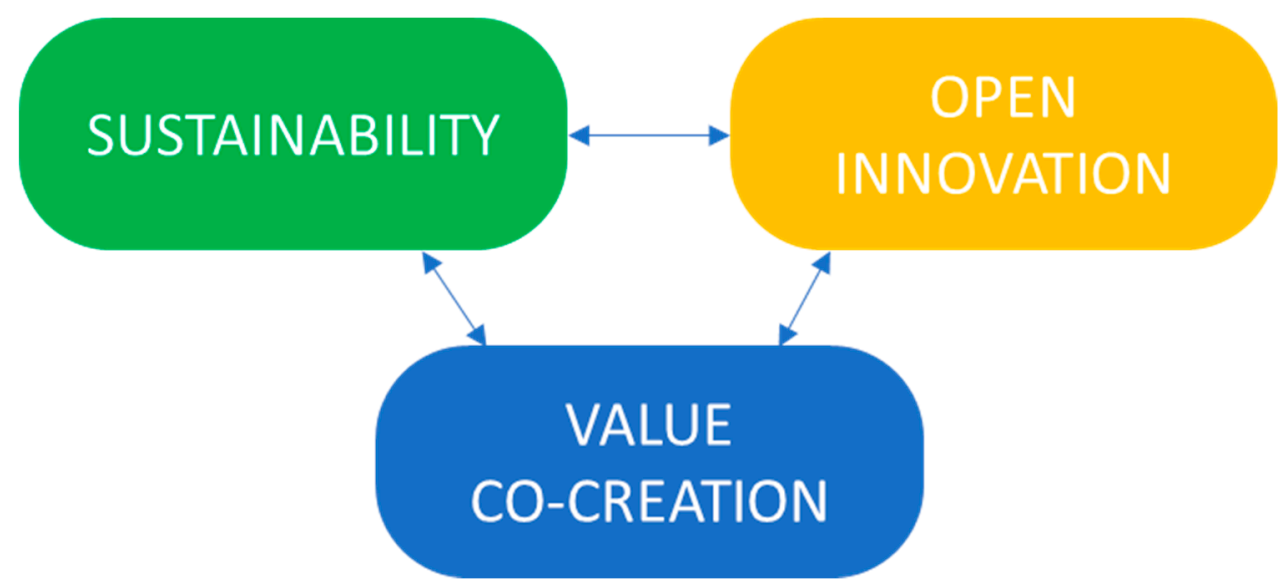

Figure 1. Theoretical framework based on SUS, OI, and VCc paradigms.

In the perspective of Kuhn [28], a paradigm is the whole world view in which theory and limitations (as acceptable degree of error) are covered. It can also be defined as a conceptual structure, or a theoretical perspective (a) shared and accepted in the scientific community of a specific discipline; (b) founded on previous knowledge in the same discipline; and that (c) operates by addressing the research in terms of (c1) identification and choice of relevant event to study, (c2) formulation of a hypothesis through which to position an explanation of the phenomenon observed, and (c3) preparation of necessary empirical research techniques [29] (p. 18).

In the specific case study examined in this research that is along the design process in a project context, the three paradigms are useful for interpreting the phenomenon observed (Section 4), as they reflect the innovation co-created in this open, collaborative way, which is finalized to create a new product, along with the co-created value through interaction between the multiple stakeholders engaged in the value network and sustainability. The latter, under the perspective of the Triple Bottom Line (TBL) framework, represents a cultural aspect that has characterized all the strategic decisions and operational policy of the case and is found in the economic, social, and environmental implications of the case study, following the explanation of each paradigm of the framework and the interactions between them.

\subsection{Sustainability Paradigm}

The topic of sustainability involves various disciplinary areas and, in an environmental optic, is today considered an indispensable value in the model of modern development, acknowledged to be no longer measurable just in terms of monetary wealth but also in terms of wider, long term meaning including respect for nature. Over thirty years ago, the well-known Bruntland report issued by the World Commission on Environment and Development (WCED) (1987) launched the idea of "sustainable development" with regard to an anthropocentric or human-centered approach as a way to "meet the needs of the present without compromising the ability of future generations to meet their own needs" [30] (p. 8).

The aforementioned definition remains a milestone in the world debate on sustainability, though more recent studies have in part questioned its validity, shifting attention to a form of transdisciplinary thinking that focuses on the connections among fields as much as on the contents of those fields involving the development of new concepts, methods, and tools that are integrative and synthetic, non-disciplinary and analytic, and that actively create synergy, not just summation [31].

In the virtuous, complex path towards a more sustainable future [32,33], an important role is played by the so-called sustainable entrepreneurship [34]. This notion starts from the belief that human beings seek value across a fairly wide spectrum that includes social value (creating beneficial 
relationships), economic value (increasing wealth), and environmental value (ensuring perpetuity in the natural environment) [35,36].

From a management perspective, protection of the natural environment is currently part of the strategic vision adopted by private, public, and non-profit organizations oriented towards adopting proper environmental management tools to reduce impact on the environment caused by the life cycle of products [37]. This perspective fosters innovation toward finding solutions that are not only focused on production phases but that are also oriented towards reducing the environmental impact and extending the valuation, since the choice of raw materials and the use of products coherently form a "from cradle to grave" philosophy.

Modern businesses interact with the external environment using new dynamics, mostly unknown in the past, and this innovational path is inspired by a growing consciousness of the need for reducing the impact of the firm on the environment, thus assigning a role of primary importance to sustainable development.

The notion of sustainability must be identified from a wider point of view, as today's challenge is to define operational and consistent terms of sustainability from an integrated social, ecological, and economic system perspective. In other words, sustainability leads to the multifaceted concept of balancing the triple bottom line (TBL) $[17,38]$ of economic, social, and ecological goals $[36,39,40]$. Thus, both public and private institutions are, directly or indirectly, increasingly involved, and are called on to be responsible (and accountable) for the results of their actions on the environment [41].

\subsection{Open Innovation Paradigm}

Innovation is a significant driver of firms' performance [42,43], as has been pointed out in the managerial literature over the last 85 years [44-54].

From another perspective, innovation has led to a rise in competitive standards in many areas, making it more difficult for businesses to reach market success [55]. However, innovation always represents a change [56] and can be considered as "one mechanism through which a firm gains superior insight about, and access to, firm-specific resources with positive future value" (p. 390). According to Adrian Smith et al. [57], "the challenge for innovation no longer rests solely in economic potential, but also in the societal changes induced by innovative activity and the consequences of this for environmental and social sustainability" [57] (p. 437).

From literature, different types of innovation have been defined, as, e.g., radical or incremental. The first one "concerns the development of new business or product lines-based on new ideas or technologies or substantial cost reductions-that transform the economics of a business and therefore require exploration competencies" [58] (p. 5). The second one "introduces relatively minor changes to the existing product, exploits the potential of the established design, and often reinforces the dominance of established firms" [59] (p. 229). Although both radical and incremental innovations "describe different types of technological process innovations", the first "are fundamental changes that represent revolutionary changes in technology" [60] (p. 1422). Linked to the previous and depending on the innovative specific capabilities of the organizations in the context of high technologies, it is possible to describe also the exploitative and explorative innovations. The first one "is based on intensive search, which means experimentation along an existing knowledge dimension", while the second one "includes things captured by terms such as search, variation, risk taking, experimentation, play, flexibility, discovery, innovation" [61] (p. 71). Considering the aim of this work, the radical innovation is the kind of innovation that is more suitable to explain the case study investigated.

There is a widespread, shared awareness that it is preferable for realizing successful innovations through collaborations between two or more actors, and also through a network [55,62-64]. Starting from this concept, the transition from closed innovation to open innovation is provided by Chesbrough [13]. In the former, firms generate innovation ideas and "then develop, build, market, distribute, service, finance, and support them on their own" [13] (p. 20) [65] (p. 2). Open innovation (OI), instead, represents a paradigm that proposes opening up firm innovation 
processes, enhancing and sustaining appropriate collaboration with different external players to create, develop, distribute, and commercialize innovations, keeping ahead of the competitive global game and getting new products/services to market before other firms [13,14,65-68]. Since the pioneering work of Chesbrough [13], OI has caught the attention of scholars around the world, gaining a growing position in managerial studies [15,69]. This new paradigm assumes a different perspective regarding the concept of innovation: it is considered not a single and linear process of internal company $R \& D$, but an interactive process of discovery, development, and exploitation of new ideas between firms' internal resources and external partners $[13,49,70]$. These external partners can include customers, suppliers, experts, universities, private/public R\&D institutions, competitors [14], the general community as a whole, and also, directly, a range of institutions inside the innovation system [51,71-74]. Collaboration with partners such as universities and public/private research centers is usually linked to the will to or necessity of acquiring new scientific knowledge $[75,76]$ (sharing them in the network context), also deemed useful for strengthening firms' internal technological competencies. This collaboration can also harden the knowledge and skills (not yet present in the firm) that are related to the management of research programs, which are essential for success of the innovative process [77-79].

Starting from Chesbrough [13], Gassmann and Enkel [80], and Enkel et al. [81], it is possible to understand how firms apply OI activities to sourcing and commercializing external knowledge. The definition of the three core OI process archetypes is provided: inbound, outbound, and coupled. The first one, outside-in process, refers to the internal use of external knowledge from partners, universities, research centers, etc. The second one, inside-out process, refers to the external exploitation of internal knowledge. The third one is comprised of the joint outside-in and inside-out processes.

In the first case, the firm looks at the competitive environment to capture possible technological solutions and knowledge that can be added to what they already have. This is the case in which the firm has "absorptive capacity", defined by Cohen \& Levinthal [12] as the ability of the firm to be able to identify, assimilate, and apply external knowledge in the firm.

In the second case, firms do not only rely on internal technological paths but also try to exploit their capabilities through the commercialization of specific technology/knowledge or through other ways [14]. Activities in this way can be various and varied as, for instance, licensing, alliance, and technical/scientific consultancies [13,82-88].

In the third case, "two actors (typically organizations) continue their separate efforts at creating innovation and other useful knowledge, but then share that knowledge" and, when they interact, the knowledge "takes place outside one particular firm" and innovation outputs are "being created in a collaborative activity of all parties together" [21] (p. 38), [15] (p. 5).

From empirical studies on OI, it emerges that firms consistently carry out more inbound than outbound activities $[83,85,86]$, which shows that firms fail to fully grasp the potential benefits of adopting OI practices.

\subsection{Value Cocreation Paradigm}

The application of knowledge and skills (competencies) by one entity for the benefit of another is called "service" $[22,23]$, so "the value is created collaboratively in interactive configuration of mutual exchange" [7] (p. 145). This value-creation configuration in so-called service systems, as well as the "study of service systems and of the co-creation of value within complex constellations of integrated resources", is the so-called service science [7] (p. 145) [89,90]. Therefore, in the context of service (and more specifically using a Service-Dominant Logic perspective) the "value is always co-created jointly and reciprocally in interactions among providers and beneficiaries through the integration of resources and application of competencies" [7] (p. 146). So, the value cocreation "is the process of creating something together in a process of direct interactions between two or more actors, where the actors' processes merge into one collaborative, dialogical process" [91] (p. 209). 
Starting from the work of Prahalad and Ramaswamy [92], the VCc concept has captured ever-growing attention of scholars who have worked on the issue from different perspectives in literature concerning marketing and post-modern marketing, as well as service (service management and-individually or simultaneously—service-dominant logic). But it is in management studies that VCc is considered as an emerging paradigm $[15,92]$.

The VCc paradigm provides a clear framework that is useful for understanding how to add value to "existing value" [93] or for using this latter concept to facilitate the growth process through interactions between the firm and actors. It describes how actors can be involved as active partners through multiple interactive channels in service innovation. The basic assumption in such service systems is the interaction for the cocreation of value [94]. "The firm's roles in value creation, the proposition of value and provision of service, are intermediary to the value cocreation process. Value propositions establish connections and relationships among service systems" [7] (p. 148). The interactions "can be understood as the locus of value because it is thanks to them that engaged individuals have experiences, to be interpreted as the basis of co-created value" [15] (p. 2). These interactions represent the way in which exchanges are handled and are regulated by the extent of relationship between two or more actors in a partnership, in a market, or in a network as part of it. The information exchanged is an important condition for co-creating value.

The service-dominant (S-D) Logic is "[ . . ] ] an alternative to the current (goods-) dominant logic", "[ ... ] a lens, mind-set, through which phenomena can be viewed" [95] (p. 105); it is focused on the process of serving other heterogeneous parties (i.e., firms, customers, and network partners), in which each party's skills, competences, and capabilities interact with the others to co-create value and several benefits for all of them [7]. The source of value and the purpose of exchange come from "specialized knowledge and abilities that people do for themselves and others (i.e., service, applied abilities) and the activities they want done for them, not the goods, which are only occasionally used in the transmission of this service" [96] (p. 47). The S-D logic has been enriched by several authors and from different perspectives, from which it has been adapted to specific contexts and related to different approaches to signal its usefulness in understanding the essence of exchange processes.

\subsection{Integration of the Three Paradigms}

To fully investigate the proposed framework, a literature review was carried out. The review was conducted with the following keywords search: "Sustainability", "Open Innovation", and "Value co(-)creation", and was realized using the same keywords with the term "paradigm". The main aim of this review was twofold: firstly, to verify the originality of the framework, and, secondly, to investigate the result. To date, the proposed framework involving the three SUS, OI, and VCc paradigms, based on the multiparadigm approach, has turned out to be original and therefore unique.

From literature it emerges that there are various studies that have explored the best way of combining the concept of OI and VCc $[97,98]$, identifying value co-creation as a possible path towards open innovation, and more recently also for linking emerging paradigms [15]. The context of OI is an ideal field for VCc, as it is characterized by collaborations, partnerships, networks, or forms of interactions, generated by relations of mutual exchanges for a common intent: reducing the risks and maximizing the outcomes. So, the link between OI and VCc can be identified by the following keys: (1) Interactions and relations are win-win between the actors of the network (with a specific scope), so the first two terms can be considered as enhancer of the value cocreation; (2) Knowledge sharing is realized by the resource integrators (involved in the value cocreation processes) to contribute benefits to others [22]; (3) When in a network involving public entities, value is co-created also through institutional arrangements [99]; (4) A relational view can increase stakeholder engagement and facilitate knowledge sharing, and therefore the emergence of value propositions.

The first point is also dealt with in the area of project management. For instance, in the fifth edition of the Project Management Body of Knowledge (PMBOK) Guide, a new area of knowledge was added: the management of project stakeholder [100], referring to managing relationships with 
project stakeholders [101]. Considering that "not all interactions between service systems co-create value" [102] (p. 20), in a value network established for specific innovative projects, a relational view [4-6] can reduce this weakness, strengthening interactions between the multiple actors involved and thus favoring the emergence of value propositions for VCc. In the context of projects, the second point brings a significant advantage that consists of optimizing time constraints through the lead time of the design processes. The third point provides for the possibility that public entities are part of or support the network (or project). The support can be, e.g., of a financial nature, and the advantage in this case is twofold: from one side the funds to carry out the projects (also in cofounding form); from the other side, the institutional arrangements that facilitate the project development with specific and formal rules and procedures. Also, this last point, as for the knowledge sharing, can support the optimization of time constraints in managing innovative project. The fourth and last point represents an opportunity for strengthening the common expectations of each stakeholder involved in the network, understanding the relational view as a mindset that can facilitate the stakeholder engagement, and from this point obtaining more knowledge sharing and value propositions (as part of value co-creation process).

Through a strategic lens, studies on the combination of paradigms between OI and SUS are provided by Chesbrough and Appleyard [103]. It is stated that firms and whole industries "are experimenting with novel business models based on harnessing collective creativity through open innovation"; "many of these experimenters now are grappling with issues related to value capture and sustainability of their business models, as well as issues of corporate influence and the potential co-option of open initiatives" [103] (p. 57). Innovation must be characterized by sustainability. "Through OI, companies can leverage knowledge management to an asset that promotes sustainable innovation in terms of a social, environmental (or ecological) and economic point of view" [104] (p. 476). The integration of OI and SUS is also described in the agro-food system and its operationalization which is "aimed at re-designing the whole set of farming practices and, to that end, at enhancing and integrating different sources of knowledge" [105] (p. 1400). Another interesting point relates to "sustainable oriented innovation" (SOI). The interaction between these terms is considered as "an important mechanism to address SOI, as internal company members are often not fully aware of potential social and environmental impacts" [106] (p. 2413).

Regarding the interaction between the SUS and VCc paradigms, no significant works investigating interactions between the two paradigms or that propose a model were found.

The framework that is based on the multi paradigms of OI, VCc, and SUS proposed in this work represents a good lens through which to read a real phenomenon. The virtuous interaction among OI, VCc, and SUS introduced in Figure 1 can explain important synergies in perceiving common goals when cooperating on innovative projects.

Assuming this lens, the overlapping areas within the above-mentioned approaches can be interpreted as the way followed by the network that enhances the achievement of the declared aims and fulfills benefits for each partner (Figure 2). This way of managing relations in the value network through the relational view [4-6] can be considered as an enhanced form of support for stakeholder engagement, facilitating the emergence of value propositions from each partner involved with the aim of maximizing the outcome of value cocreation [5] (p. 230). 


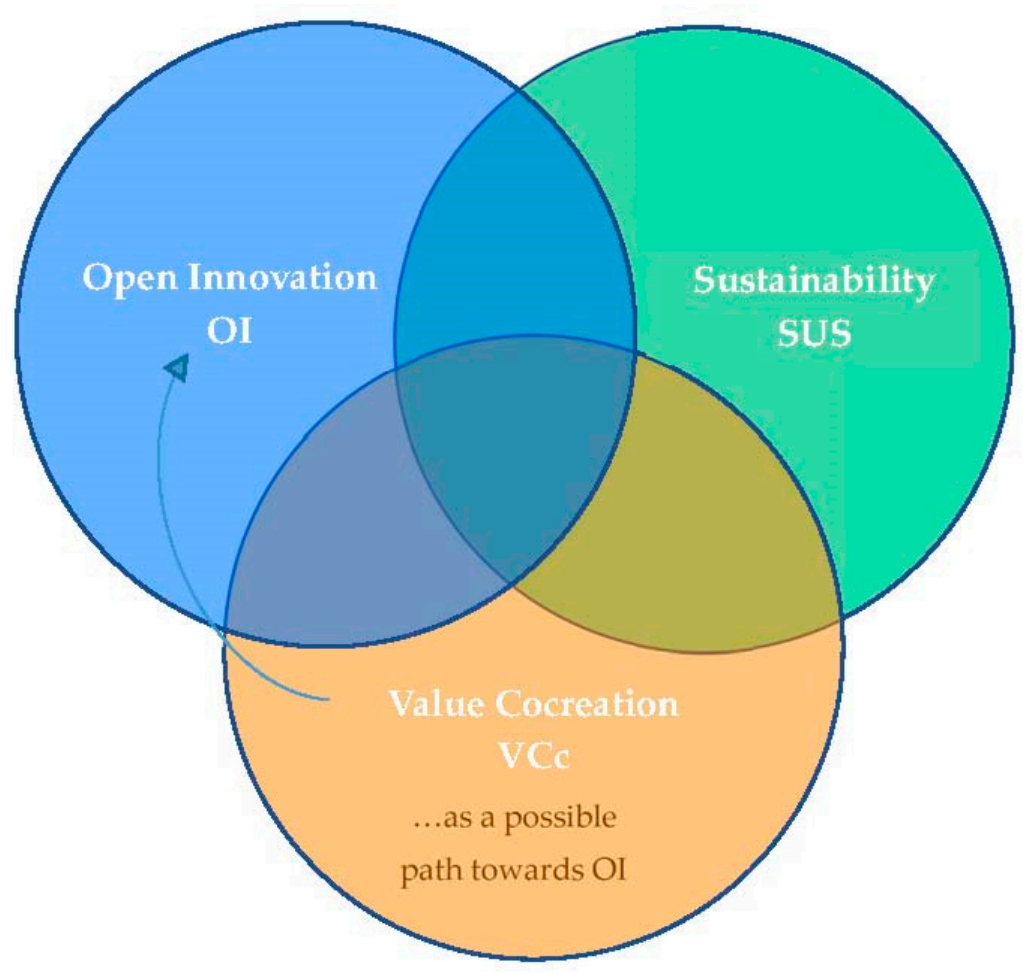

Figure 2. The interactions between the paradigms.

\section{Methods and Data}

With the aim of exploring the significant implications of the three paradigms outlined in the conceptual framework, the case study research method was adopted. This approach is considered appropriate for our purposes in that it allows a more precise, detailed examination of the subject matter compared to other methods [20]. Furthermore, this method enables us to understand the complexity of the activity in which multiple sources of evidence are used and much information is identified [20].

We deemed the TESEO network as a typical case [107] concerning the implementation of sustainable technology, adopting both OI and VCc paradigms. This network was considered a suitable setting for our investigation for two main reasons: first, it represents a test bench on how to build the bridge between OI and VCc in line with sustainable development; second, it aids in the finding primary documents for in-depth analysis. Indeed, we had the opportunity to explore the phenomenon under investigation thanks to easy access to internal documents, as well as official project reports, as one of the authors of the research is the president of the board of statutory auditors of the Sicilian Maritime Cluster "Navtec", the collaborative network within which the TESEO project was developed. This extraordinary circumstance, as is well-known, represents a favorable condition under which to make the selection of a case study [108].

The research is based on combined data collection tools and makes use of diverse types of materials, methods, and investigations [109]. Different data sources were used, such as: (a) official documents, Internet documents, published interviews; (b) scientific papers; (c) semi-structured interviews with key informants; (d) informal follow-ups based on e-mails and short phone interviews [20]. The document analysis was conducted skimming (superficial examination), scanning (thorough examination), and interpreting data, as an iterative process that combines elements of content analysis and thematic analysis. Through a careful, more focused re-reading and review of the data, as well as category construction based on data characteristics, the analysis tried to uncover themes pertinent to the phenomenon under investigation. Particularly, the research detected the themes, as well as related words: innovation, cooperation and coordination, value creation and 
sustainability/sustainable development, and similar items deemed useful for interpretation in the context of the theoretical framework adopted [110].

As interviews were considered the primary source gathering instrument for the research, a semi-structured interview was chosen as an open-ended guideline, assuming the form of guided conversations rather than structured questionnaires [111]. The choice of the semi-structured interview was motivated by the fact that it offers enough flexibility to approach several respondents differently while still covering the same areas of data collection. Questions were carefully designed to provide adequate coverage for the aims of the research [112].

More specifically, we interviewed the scientific director, that is, the academic referent for technology transfer between research centers and industrial laboratories of R\&D; the chief engineer responsible for realization of the prototype; and some representatives of fisher association involved in the project.

They can be considered as key informants and respondents since they have detailed information on the main industrial and financial aspects of the value network [20].

The selection of fishermen interviewed was made assuming as a starting point the preliminary survey carried out by the project team, which aimed to customize the prototype to meet the users' needs and to select the best solutions for environmental protection, realizing a prototype suitable for respecting on-board comfort and livability parameters during the fishing period. Indeed, in the value network, a "sustainable value can be created only when the firm and customers' need and objectives fit, so a deep understanding of customers and their participation to the value creation process can generate solid financial results" [113] (p. 4).

Among other issues, respondents helped us to deepen some aspects deemed relevant for the analysis, such as contributions and benefits characterizing each partner involved in the project, and the risks incurred and criticalities that emerged in the coordination of the activities carried out during the different phases of the process. The interviews took place between June and September 2017, were tape-recorded to ensure an accurate account of the conversations and were then transcribed. Each interview lasted about two hours and followed methodological prescriptions on data collection through personal interviews [114]. Data derived from the interviews were integrated and triangulated with other secondary information to increase the information flow and also to allow checking of the judgment provided by the various subjects [115]. All the transcripts, after being checked by the interviewed subjects, were reported with the appropriate corrections. The interview protocol in Appendix A reports the open-ended questions that were posed to the various respondents.

Furthermore, participant observation generated insight into and better understanding of the phenomenon under study. The observed phenomena of interest in the environment studied gave the researchers the opportunity to draw on information that was not obtainable from other methods [111].

Considering the topics involved in our study, from the respondents' interpretation, we gained further insight into the meaning of SUS, OI and VCc when investigating the interdependence of actors in the project, and the model of interaction adopted.

In the following paragraph, we first outline the case study context (Section 3.1), describing the general aim of the value network (TESEO Project); Section 3.2 deals with the main aspects of the realization of the prototype of a fishing vessel (TESEO I) selected to explore the research question in depth; in the Section 3.3, we present the results of the analysis.

\subsection{Case Study Context}

As is well-known, also in the maritime sector, traditional energy systems are mainly based on highly polluting internal combustion engines (diesel) that supply energy for propulsion and electrical power. These systems are characterized by low thermodynamic efficiency that causes pollution (emissions and noise) or alteration of the ecological equilibrium, as well as of the seas and ports. Thus, widespread use of echo-compatible technologies for vessels represents a goal determined by 
the need for re-directing the entire transportation field to achieve low environmental impact and high sustainability.

The case study concerns the construction of a prototype of fishing vessel, built according to sustainability criteria using cutting-edge techniques and modern scientific knowledge. The project was financed under the National Research \& Competitiveness Operational Program (PON R \& C) funding program. Funded with European Structural Funds managed by MIUR (Italian Ministry of Education, University and Research), the program involved four underdeveloped regions in Southern of Italy: Calabria, Campania, Puglia, and Sicily.

The construction of the prototype (TESEO I) as explained below is a part of a larger project called TESEO. The acronym of the project (also the name of the vessel) stands for Tecnologie ad alta Efficienza per la Sostenibilità Energetica ed ambientale On-Board (High Efficiency Technologies for On-board Energy and Environmental Sustainability); it was chosen as it evokes the mythological figure of Teseo-Theseus, the son of Poseidon, King of the Sea.

It is worth noting that the TESEO Project is one of the many projects developed by the Sicilian Maritime Cluster "Navtec", the collaborative network founded in 2008, in the form of a consortium company, with the aim to fostering innovation in the maritime sector by promoting collaborative relationships between private industrial actors and the main public scientific organizations operating in Sicily (the three major Sicilian Universities and the National Research Council).

The mission of this collaborative network is strictly linked with fostering innovation by sharing research and development (R\&D) activities among partners, and likely the most important role of the network is to coordinate the efforts of each partner in the process, above all facilitating access to public subsidies [116]. On this topic, collaboration among firms seems to have been assigned a central role. As outlined by a recent study conducted in this field with regard to Italy, "public authorities willing to enhance firms' innovation capabilities are increasingly recognizing inter-organizational collaborations when granting public financial research and development (R\&D) incentives, also referred to as public subsidies (PS)" [117] (p. 1).

Although R\&D subsidies can alleviate firms' budget constraints and contribute to innovation, since the application process for public funding requires energies and specific know-how not always in the domain of an SME, firms under time and budget constraints, or lacking such expertise, may choose to focus on their own investment efforts rather than on public grants. The creation of a network can encourage the single firm to take this path, thanks to the external support coming from cooperation.

Furthermore, there is wide empirical evidence that public subsidies improve the efficiency of collaboration in the OI approach. As argued by Greco et al. [117], the positive effect of public subsidies on OI adoption can have three desirable outputs: (1) By enhancing OI, public grants may transitively improve fund beneficiaries' innovation performance, generating positive externalities for the society in terms of occupation and value creation; (2) Public subsidies can positively impact in environmental and social terms, especially where funds are directed towards incentivizing research fields in which a higher gap between private and social returns is assumed to exist, such as in the sector of sustainable energy; (3) Other positive externalities are expected by stimulating knowledge dissemination.

Consistent with the previous experience in this field, the role of the Cluster "Navtec" in this field is twofold: first, it supports firms, helping them to access public subsidies; secondly, it fosters interaction and cooperation of partners on R\&D activities [118]. In both cases, the network is an instrument that is able to overcome some limitations of each firm, rendering the investments carried out more effective.

The fact that the regional universities and the National Research Council (CNR) joined the network, thanks to their reputation and to knowledge-based nature, attributed a particular feature to the cooperation. Thus, as emerged in literature, their participation can produce positive effects in terms of efficacy of the OI process [119] whilst increasing trust among partners [118].

More specifically, the TESEO project, coordinated by the National Research Council (CNR) of Italy, ITAE (Messina), was developed with specific CNR institutes, the Institute for Advanced Energy Technologies "Nicola Giordano" (ITAE) Messina, the Institute for Coastal Marine Environment (IAMC) 
Torretta-Granitola, Mazara (TP), the Engine Institute (IM) Naples, three Sicilian Universities (Messina, Catania, and Palermo), and a leading Italian company in the maritime sector (CETENA-Fincantieri), as well as a Sicilian small firm (Cantieri Tringali) that is closely linked to the local context and highly specialized in certain production phases.

The general aim of the project, which is in full agreement with European Directive 2008/56/CE [120] issued for the protection of the marine environment, was to contribute to implementing energetic technologies already available for ships (fuel cell systems with hydrogen and liquid fuel, 3rd generation batteries, and photovoltaic and wind generation systems). The main purpose was to stimulate the adoption of maritime transport systems with high efficiency and low environmental impact, by preparing, at the same time, an embryonic framework for the diffusion of hybrid ships; this latter issue has been an interesting opportunity for both end-users and constructors. In this project, two general objectives were addressed: firstly, the aim to apply some energetic systems and related devices, representing the state-of-the-art of industrial research, in the area of high efficiency technologies with low environmental impact, in several kinds of ships; secondly, to create new, more advanced energetic systems, suitably developed for maritime applications. Table 1 summarizes some information that refers to timing and cost of the project.

Table 1. Timing and cost of the TESEO project.

\begin{tabular}{l}
\hline Time \\
\hline Start date-7 July 2012 \\
End date-7 July 2015 \\
\hline Costs \\
\hline Total: $€ 15,088,936$ \\
Research: $€ 10,542,997$ \\
Development: $€ 3,609,839$ \\
Education: $€ 936,100$ \\
\hline
\end{tabular}

\subsection{TESEO I, an Emblematic Case of Integration of Sustainability, Open Innovation, and Value Cocreation' Paradigms}

The realization of the prototype vessel (TESEO I), considered the most significant result achieved by the project, is here outlined following a temporal path whose sequence is deemed helpful in order to analyze (a) how the partners cooperated in this project, (b) what benefits they obtained, (c) the collaborative aspects that characterized the project, and (d) which critical aspects emerged from this cooperation.

The main purpose of the TESEO project was to develop the use of energy technology and apply it to the maritime sector. It regarded two main objectives: (1) to make available and install energy devices and systems representing the state-of-the-art in the field of energy efficient technologies on different types of vessels, and (2) to study and realize new, more advanced energetic systems directly developed for the maritime sector.

The purpose is entirely embedded with sustainable development issues that have been constantly taken into account during all the various phases of the project, in particular regarding the development of high efficiency energy technologies with low environmental impact that are to be applied in the designed and built boats.

To demonstrate the application feasibility of such technology, different types of vessels were identified, such as mega-yachts, yachts, and sailing and fishing boats. In parallel, new technologies with a strong innovation character, specifically dedicated to the maritime sector, were developed for medium and long-term application. New energy technologies that were directly tested on board were supported by structural and engineering studies, together with appropriate energetic analysis. 
In the course of the project, cooperation among the various partners was crucial in the development of the several systems addressed in the project plan. Specific testing controls were identified and applied, and appropriate subsystems were designed for every new technology.

The first objective was developed in three projects that aimed to realize a prototype or a pre-industrial product:

- Pleasure craft, such as yachts and sailboats, should use a polymeric electrolyte fuel cell. Therefore, both hybrid and purely electrical configurations were studied. Particular attention was paid to renewable sources, such as photovoltaic sources, to ensure energy sustainability and efficiency. In addition, specific studies were devoted to methodologies based on the integration of renewable energies (available on-board), which aimed to generate electricity for auxiliary systems.

- For the electric propulsion of large vessels, the project dealt with the development and implementation of a complete power generation system with a maximum power of $210 \mathrm{~kW}$, comprising control and management systems, and the study of constraints in current legislation with the purpose of issuing specific guidelines on new security criteria related to the use of new technologies and their certification.

- For small and medium size vessels, such as yachts and sailing boats, both hybrid and pure electrical engines were investigated.

To achieve high technical performance and low environmental impact, improving efficiency and reducing fuel consumption, cooperation among partners was aimed at designing a fishing vessel prototype, characterized by high innovative solutions for hull fluid dynamics and structure. At the same time, it was necessary to optimize the propulsion system by also studying different configurations with different degrees of thermal-electric hybridization. The most modern pollution abatement technologies were applied, making them suitable also for heavy duty diesel engines, such as those used on fishing vessels.

The second main objective regarded the study and development of new, specific technologies for maritime applications, which were not intended to be used to obtain prototypes or pre-industrial products within the result of the project but only to carry on in-depth studies in the specific field within the basic research.

As fishing provides a vital source of food, employment, recreation, trade, and economic well-being for people throughout the world, it should be conducted in a responsible manner, for the sake of both present and future generations. Therefore, the implementation of new, more ecological vessels could represent an important step forward towards ensuring sustainable activity of (commercial) fisheries and effective mitigation of putative risk to species and habitats of conservation concern (see Figure 3).

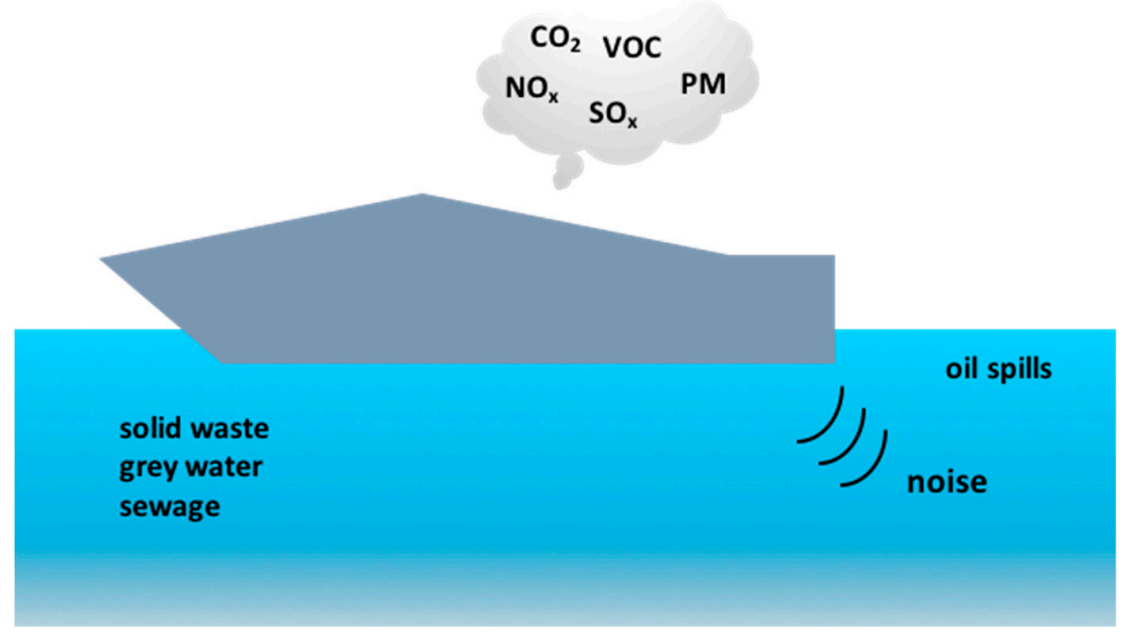

Figure 3. Potential pollution by a board. 
In line with Figure 3, one of the three projects related to the first objective of the TESEO Project involved the production of a prototype vessel for fishing: the TESEO I. The specific aim was the realization of a prototype of high efficiency and low environmental impact that, at the same time, was able to meet the needs of comfort and safety of fishermen during the various phases concerning their activities on board. Indeed, over the period of the development of the prototype, not only were issues identifying innovative solutions consistent with low environmental impact considered, but quality, reliable, sustainable, and resilient infrastructure to support well-being on board was also promoted and realized.

TESEO I, realized according to the aforementioned objectives, has characteristics that make it completely compatible with the sustainability principle.

Moreover, it represents the result of a concrete example of how OI, which is a pervasive aspect of the project, can be linked to VCc in the implementation of economic, ecological, and social solutions obtained through knowledge sharing.

Retracing the various phases (from the generation of the idea to its development) of the realization of TESEO I, it is clear that the outward opening aimed at VCc regards, almost indiscriminately, all the phases of the process, even if to different degrees. They will be described below, highlighting the contribution given by different partners, each with their own specific knowledge. The following Table 2 shows the partners involved in the construction of the prototype.

Table 2. Partners involved in the construction of the prototype.

\begin{tabular}{cc}
\hline Partners & Province, Country \\
\hline CNR ITAE (Coordinator) & Messina, Italy \\
CETENA & Palermo, Italy \\
Cantiere Tringali Srl & Augusta, Italy \\
Informatica Navale S.a.s. & Naples, Italy \\
CNR IM & Naples, Italy \\
Distretto Agrobiopesca & Palermo, Italy \\
CNR IAMC & Capo Granitola (Trapani), Italy \\
\hline
\end{tabular}

It is important to underline that, as mentioned above, the realization of the TESEO I prototype represents, in truth, one of the conclusive phases of the wider TESEO Project. Therefore, the complex, important upfront or fuzzy front-end of the product development (FFE) [25], as a predevelopment step of the innovation process, must be considered as accomplished during the determination of the larger aims of the TESEO project.

The first stage of the activity regarded analysis of the regulatory framework and an evaluation of the real needs of the fishing industry. Different types of fishing were considered in relation to the structural characteristics of the prototype. In this phase, both CNR Sicilian institutes, ITAE and IAMC, played a primary role.

In the following stage, the designing the prototype, and the support given to the project by actual stakeholder engagement, which was carried out by the network itself, was fundamental. Fishermen, in particular, need to be mentioned for their role in building the prototype. They were engaged through a questionnaire devised by IAMC and CETENA to help identify issues related to:

- different technical and structural features when adapting the layout of the ship;

- $\quad$ specific conditions of safety that needed to be taken into account, among which was the impact of noise on people and fish;

- comfort level for fishermen, considering the long time they usually spend onboard;

- the need to customize the vessel according to the type of fishing activity;

- $\quad$ the need to ensure the correct preservation of fish in special refrigerated cells on board;

- the operating speed of the vehicle in the different phases of fishing (research, transfer, exit, and return to port) and the duration of transfers for the different types of fishing. 
This category of stakeholder was considered the most important for two reasons: first, for their specific competence on the type of fishing and then the opportunity to meet their expectations, as they are the users of the ship; secondly, for the competence of such people regarding the nature and degree of environmental impact of the vessel, along with the opportunity to learn from their knowledge and experience.

During the realization of the prototype (Figure 4), the procedure foresaw continuous inter-functional involvement always supported by the coordination activity carried out by ITAE. People responsible for the various functions were involved in working together under constant supervision. It is important to highlight that the entire management of the collaboration took place not only through frequent meetings but also through the use of technological communication tools and highly professional, scientific software.

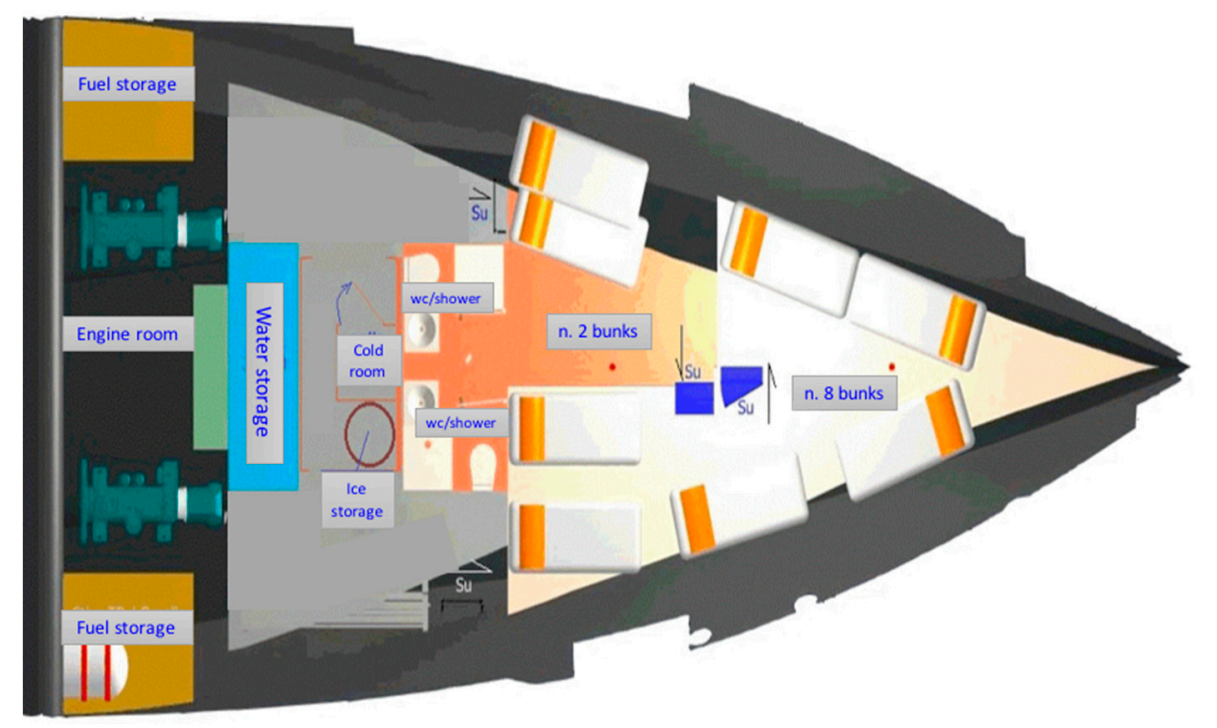

Figure 4. The livable area projected by fishermen (Source: Tringali Shipyard).

Having collected and checked data related to the questionnaire, boat features were tailored to the needs of fishermen, considering permanence on board of 10 people for 3-5 days maximum, with intermediate support from other ports.

Researchers were looking for innovative solutions for the hull that addressed the optimization of fluid dynamics of the keel, and different types of hull were defined and studied through numerical simulations and hydrodynamic analysis to assess hydrodynamic performance and optimization.

In this phase, Informatica Navale and Cantiere Tringali were supported by CETENA S.p.A. (a Fincantieri Company), an important study center in the maritime field, located in Castellammare (Palermo). As well as needs relating to livability on board (see Figure 4), the propulsion system was developed by studying possible configurations of different degrees of thermal-electric hybridization and designing the propeller to maximize efficiency and silence of the ship.

Great emphasis was put on optimizing the hybrid propulsion system. Taking into account performance and overall requirements on board and the relative fishing operations, CNR IM, Informatica Navale, and CETENA, together with the technicians of the Cantiere Tringali, identified a specific diesel-electric hybrid architecture. The solution allowed the adaptation of the hull profile to fishing and the achievement of high efficiency by reducing pollutant emissions. Diesel engines can be switched off when maximum power is not required, for example, at the moment the nets for fishing are down (Figure 5).

Greater efficiency of the boat and reduction of fuel consumption were obtained thanks to innovative solutions found for the fluid dynamics of the keel and hull structure. The most modern 
techniques for reducing polluting emissions were also evaluated. In particular, CETENA S.p.A. provided a fundamental contribution to the hull design through optimization of the hull shape and propeller tunnels, in particular with reference to levels of radiated noise. Structural solutions were also developed, aimed at improving hull resistance without increasing the weight of the boat, and at the same time a more rational redistribution of the components' weights of the hull resulted in greater stability of the boat.

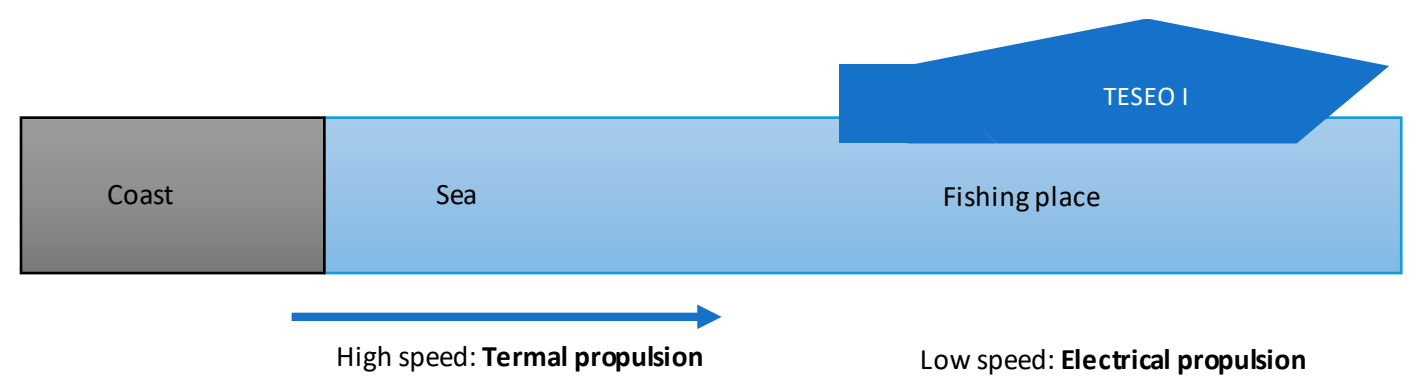

Figure 5. The mechanism of pollution reduction.

The next step involved the construction and preparation of the vessel prototype. This phase was carried out at the Cantiere Tringali, located in the port of Augusta (Syracuse). After having prepared the construction plan and drawings that were related to the type of single-hull vessel, types of systems and accessories on board were identified, as well as the materials to be used. The engineering-structural study of the hull for the evaluation of spaces, dimensions, and weights also concerned the fishing plants, refrigeration, and preservation of the catch on board, and a sizing of their maximum. In this phase, it is worth citing the participation of another CNR institute, IM in Naples, which aimed at improving combustion efficiency, choice of the particulate filter, and the hybrid on-board propulsion and power generation architecture. As well as other activities carried out within the project, also the construction of the prototype in the Cantiere Tringali was coordinated by ITAE, which also developed, realized, and tested the specific components of an adsorption cooling machine for the preservation of the catch, which uses the waste heat produced on board during navigation.

The realization of the prototype was completed with the construction and launch of a semi-displacement hull, with an innovative design concept $17.44 \mathrm{~m}$ in length, width $7.62 \mathrm{~m}$, height $2.70 \mathrm{~m}$, built entirely in steel, $4 \mathrm{~mm}$ grade. Stability tests were carried out on board with positive results for obtaining the final test.

There are two key points that make the experimental prototype decidedly innovative for high energy efficiency:

(1) Dedicated Maritime Geometries;

(2) Hybrid propulsion.

With regard to the first point, the main geometric innovation lies in the hull of the prototype based on the principle of "partial hydrodynamic sustenance" that, compared to a conventional displacement boat, ensures higher speeds at equal power. A second distinguishing aspect is the empty weight of the prototype, which is less than half compared to the traditional type but is able to ensure the same commercially useful flow rate. A further innovation is the geometric profile form with a drastic reduction of the sail area, which is used to get a better grip to leeway during mail operations. Finally, the advantage offered by the new geometry concerns the safety and comfort of the crew, thanks to the considerable increase in the area of Covered Bridge, which is available for the equipment and operation of the vessel (see Figure 5), as well as the increase in accommodation space for 10 people.

The second key point is the introduction, to the fishing sector, of hybrid propulsion, the simplification of plants, and the control and management of energy resources. For the type 
of fishing envisaged, it will be possible to use only electric motors in fishing zones to maintain position or move at very low speeds during the phases of lowering the fishing gear.

A comparison with existing fishing vessels from an energy point of view, through the forecast analyses conducted, indicates a significant reduction in diesel consumption resulting from the combined effect of the two above-mentioned characteristics, giving the vessel greater energy efficiency with consequent lower environmental impact and a lower operating cost. This may pave the way for the modernization of the fishing fleet, also in view of the selectivity of fishing gear and the preservation of fish on board which, by increasing the value added by the fishing vessel, improve the cost-benefit ratio of the fishing activity.

\subsection{The Results}

Working through the design process of the realization of TESEO I has given us the opportunity to better understand that value of co-creation, which is seen as a possible way towards open innovation; this point has already been highlighted in the theoretical background. More precisely, from case study it emerged that the co-creative process is linked with the innovative process in a general context deeply inspired by sustainability since energy saving, resulting in a reduction of greenhouse gas emissions, which represents one of the foremost global environmental issues.

Indeed, it is well known that OI can be characterized in terms of level of integration, organization, and forms of governance [121] but according to Lanzarotti and Manzini [122], studies of other variables are significant to OI: "namely, the number of and types of partners and the phases of the innovation process which are "open" to external contributions" (p. 616). On this topic, "the number of and types of partners with which a company collaborates is something that determines the level of openness of the innovation process of a company: the more partners the company has, the more "open" its innovation process", as well as "the number and type of phases in the innovation process for which the company accesses external sources of technology and know-how" [122] (p. 616), giving information of openness of the innovation process [123].

From literature, a number of different approaches are used to measure the degree of openness of companies, which are consistent with the multidimensional nature of the phenomenon [124], but the use of the two aforementioned different variables is considered useful to the aim of this paper. This approach is consistent with the fact that the various stages in the innovation process have very different features, and OI can be addressed only to specific phases, such as idea generation [123] prototyping and engineering and production [125].

By focusing on such variables starting from the first and until the last phase, we measure the degree of OI also by considering the number of and type of partners involved in each process; see the Table 3 below.

As said above, the context of OI represents an ideal environment for VCc, which is considered as a dynamic and continuous process that is able to cocreate stable value in the long run, engaged each time in different ways and generating different "values" both for firms and individuals in a continuous cycle [126].

The model proposed in this work regards the coupled process of OI and fits with the investigated case study, as this kind of OI process is realized when partners actively collaborate and cooperate [81] and thus when outside-in and inside-out processes are run simultaneously [127]. Moreover, the network in which the cooperation took place led to an authentic co-creation of value in which each individual co-creates value and captures it continuously in different forms and ways over time. The suitable application of different knowledge and skills, together with the integration of resources and enforcement of competencies, enhanced the value of each entity by creating benefits for all partners into one mutual exchange through a collaborative and dialogical process. In this context, a variable that undoubtedly impacted the designing process is time, a strategic factor that deeply influences innovation processes in terms of development, adoption, and diffusion of technology. Indeed, the lead time played a crucial role in this project, in which many actors were asked to act under a common 
management, given the need to coordinate the various phases and the simultaneous contribution required from each one, to achieve the goals of the entire project.

It is acknowledged that the time factor is fundamental in every environment, sometimes representing a not negligible obstacle to overcome, especially for SMEs that have fewer organizational resources with which to address research activities that are embedded in managing innovation processes. This aspect represented one of the major challenges, and the synergic and synchronic cooperation of actors required a great deal of effort (also considering problems faced during the process that were not foreseeable in advance). The case under investigation, as well as others studies in literature $[122,128]$, demonstrate the importance of the time dimension along with the achievement of different innovation goals.

The previous Figure 6 shows tasks and phases detailed in the project, which were assigned to the various partners, considered also in reporting documents required by public administration as lead time to respect for the success of the process. It allows a deeper understanding of the complexity of the interaction among involved actors.

Table 3. Degree of open innovation considering the number and type of partners involved in each process.

\begin{tabular}{|c|c|c|c|}
\hline Month & & Phases of the Innovation Process & $\begin{array}{l}\text { Assignment of Phases } \\
\text { to the Partners }\end{array}$ \\
\hline M 1-11 & 1 & $\begin{array}{l}\text { Definition of the regulatory framework and analysis on } \\
\text { the real needs of the fisheries sector }\end{array}$ & CNR-IAMC, Cetena \\
\hline M 1-18 & 2 & Preparation of the construction plan and the drawings & $\begin{array}{l}\text { Cantiere Tringali Srl, } \\
\text { Informatica Navale Sas }\end{array}$ \\
\hline M 1-30 & 3 & $\begin{array}{l}\text { Analysis of the different types of fishing that can be } \\
\text { conducted in relation to the structural characteristics of the } \\
\text { prototype }\end{array}$ & CNR-IAMC, Cetena \\
\hline M 1-34 & 4 & $\begin{array}{l}\text { Search for innovative solutions for the hull addressed to } \\
\text { the optimization of the fluid dynamics and the structure of } \\
\text { the hull itself }\end{array}$ & $\begin{array}{l}\text { CNR-IAMC, Cetena, } \\
\text { Informatica Navale Sas }\end{array}$ \\
\hline M 1-42 & 5 & $\begin{array}{l}\text { Integration of activities of project TESEO I with those of } \\
\text { PESCATEC project supported by Agrobiopesca } \\
\text { technological district }\end{array}$ & CNR-IAMC \\
\hline M 3-30 & 6 & $\begin{array}{l}\text { Engineering-structural study of the hull for the evaluation } \\
\text { of spaces, dimensions, and weights }\end{array}$ & $\begin{array}{l}\text { Cantiere Tringali Srl, } \\
\text { Informatica Navale Sas }\end{array}$ \\
\hline M 3-30 & 7 & $\begin{array}{l}\text { Implementation of the executive design, detailed } \\
\text { engineering, and approval of the classification body }\end{array}$ & $\begin{array}{l}\text { Cantiere Tringali Srl, } \\
\text { Informatica Navale Sas }\end{array}$ \\
\hline M 3-24 & 8 & $\begin{array}{l}\text { Development of the main components of the adsorption } \\
\text { refrigerating machine for conservation of fishes }\end{array}$ & CNR-ITAE \\
\hline M 7-24 & 9 & Application study of after-treatment of exhaust gases & CNR-IM \\
\hline M 7-25 & 10 & $\begin{array}{l}\text { Study of hybrid engine variants, with different levels of } \\
\text { electrification }\end{array}$ & $\begin{array}{l}\text { CNR-IM, Informatica } \\
\text { Navale Sas }\end{array}$ \\
\hline M 7-42 & 11 & Study of systems for monitoring the propulsion system & Cantiere Tringali Srl \\
\hline M 9-42 & 12 & $\begin{array}{l}\text { Optimization of the main engine for reducing fuel } \\
\text { consumption and emissions }\end{array}$ & CNR-IM \\
\hline M 13-33 & 13 & $\begin{array}{l}\text { Study of new propulsion schemes in order to obtain the } \\
\text { best performances and an accurate management of the } \\
\text { irradiated noise }\end{array}$ & Cetena \\
\hline M 19-42 & 14 & $\begin{array}{l}\text { Prototype assembly of adsorption chiller (proof of concept) } \\
\text { for the conservation of fishes by using waste heat available } \\
\text { on board }\end{array}$ & CNR-ITAE \\
\hline M 20-42 & 15 & Prototype realization & Cantiere Tringali Srl \\
\hline M 34-42 & 16 & Tests, checks, and final tests & Cantiere Tringali Srl \\
\hline
\end{tabular}




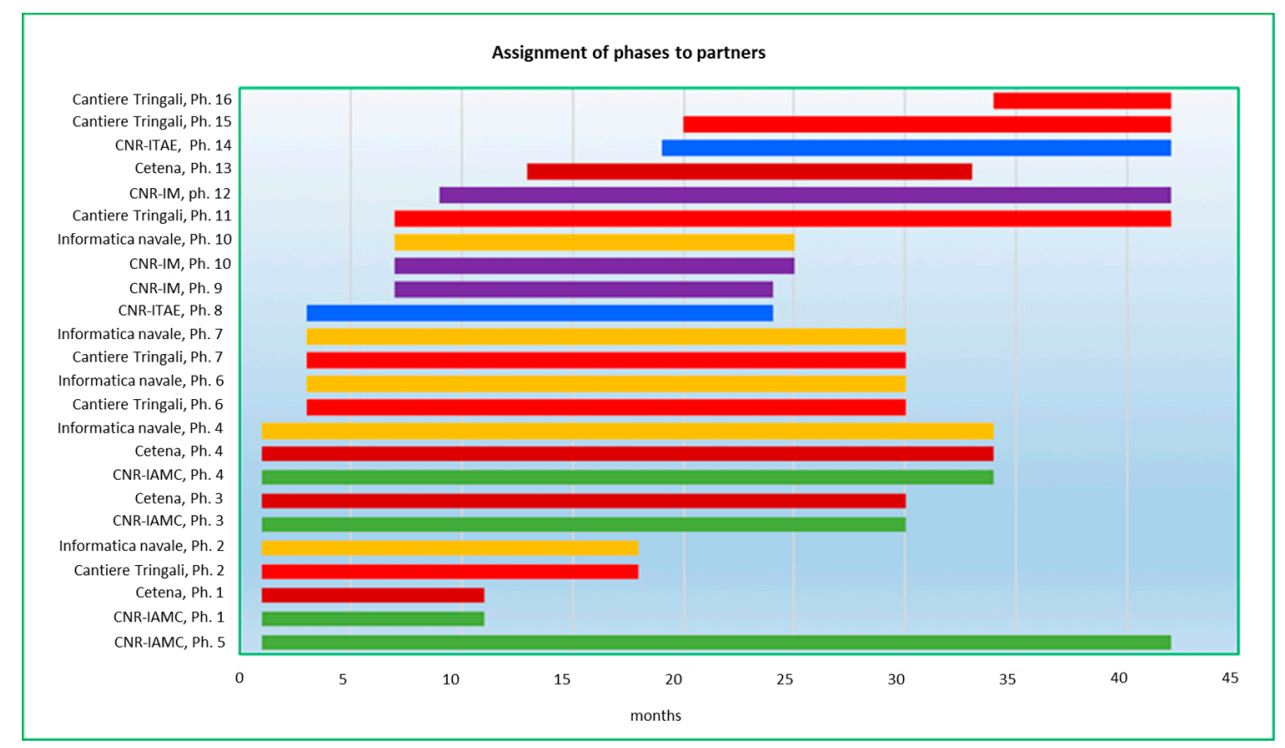

Figure 6. Assignment of phases to partners.

\section{Discussion}

This section discusses the results of the case study that deals with a radical innovation in a maritime cluster, as well as the proposed multi paradigms framework as a valid lens, deemed useful for reading a real phenomenon. Theoretical and practical implications are also provided.

The case investigated reveals how each partner of the value network interacted with others in a platform of involvement, co-creating value for themselves and for others, regardless of whether it acted only in its own interest or even in the interest of the structure to which it belongs [93].

Regarding the benefits of the realization of the prototype for each partner, it is important to highlight that these benefits are particularly concerned with the results that were already transferred in the production phase- those that require further development for the purpose of a possible transfer to production and the benefits that derive from the increase in knowledge applicable to further R\&D programs.

Each result represented a different kind of advantage for each partner.

The greater energy efficiency, lower environmental impact, and greater functionality also for the part related to the fishing equipment of the boat opened the way for the Tringale Shipyard in industrial production, which was able to modernize the fleet of fishing vessels, especially in the Sicilian sea.

The research bodies involved, each for their own competences, have been able to acquire deeper technical knowledge of the problems faced, testing the theory, in practice, and contributing to the dissemination of research results. They improved their capacity to share their knowledge, working together and interacting with industrial partners to validate technical solutions studied in their laboratories with regard to the possibility of industrial exploitation of theoretical results.

The application of hybrid engines in the maritime field and for fishing represented a meaningful novelty for the research institutions (ITAE, IAMC, and IM) with regard to the study of the best energy saving solutions. Although, in fact, the use of engines powered by electricity is spreading worldwide, specific studies on their use in marine environments can be considered at an early stage, and the experience achieved so far thanks to the realization of the prototype can be considered as of primary importance for improving future marketable solutions in this field. Concerning this point, it should be pointed out that a critical aspect that emerged in the phase of the use of the hybrid engine in the prototype was the difficulty of locating some components in the market, since suppliers had never received a request for this kind of application. 
Another aspect that deserves to be stressed is the role of stakeholders' engagement in the project, with particular regard paid to the end user of the fishing vessel. The fishermen, involved in the survey through their own co-operative association, provided useful information regarding the main issues to consider in the building of the prototype, given that the quality and usefulness of any product must be evaluated in the perspective of the client. Indeed, the functions and attributes of a product are valuable, that is, they have value if they add value for the users. Moreover, their support was important in enhancing the ecological compatibility of the fishing boat. Nonetheless, the engagement of fishermen, deemed neither negligible nor avoidable, led to delays in the production process, due to the difficulty of interacting with their association. Moreover, communication was to some extent difficult due to the lack of shared language codes on some technical aspects.

In the light of the above, we can say that the case of TESEO I, selected as the focus of the research on the link among the three paradigms-SUS, OI, and VCc-demonstrates how such paradigms converge when environmental and economic results are pursued through modern forms of cooperation on innovative projects that aim to co-create value. Table 4 shows the various dimensions relating to realization of the TESEO I prototype. TESEO I can be considered best practice in the development of a new product through knowledge sharing, being a tangible result of how to improve economic and ecological performance through cooperation, and of how OI can be linked to VCc and SUS.

Table 4. The dimensions of coupled OI processes that lead to environmental and economic value cocreation for TESEO I (Own adaptation by [15]).

\begin{tabular}{|c|c|}
\hline Dimensions & $\begin{array}{l}\text { Dimensions of Coupled Open Innovation Processes Leading to } \\
\text { Environmental and Economic "Value Co-Creation" }\end{array}$ \\
\hline Actors & $\begin{array}{l}\text { - Public scientific support for innovation (CNR Institutes; Universities), } \\
\text { - Private Industrial development of innovation (Tringali Shipyard, } \\
\text { CETENA-Fincantieri); } \\
\text { - Sicilian Fishermen }\end{array}$ \\
\hline Coupling Topology & Network \\
\hline Impetus for collaboration & Active roles for all individuals and benefits for all participants \\
\hline Locus for innovation & Interactive \\
\hline
\end{tabular}

The value cocreated with the contribution of different partners, selected on the basis of their highly specific competences, shows how it is possible for each partner to obtain benefits from collaboration, rendering the relationship active, effective, durable [15], and profitable for participants. In other words, every partner was truly involved in the OI process, and this relationship allowed for the creation of value, achieving results that are meaningful both in terms of monetary and non-monetary value (environmental and social goals). From the case study emerges that the TESEO' network was already created with the intention of adopting an open innovation logic. Concretely, the OI and VCc processes started simultaneously from the phase in which the knowledge sharing (at different levels) was verified to identify all the possible critical issues related to the project solved when the value propositions emerged from the interactions between the multiple actors involved.

Based on the theoretical background presented in this work, the TESEO case was analyzed, and we can argue that each paradigm and its theoretical purpose were found in the field study.

The interaction among SUS, OI, and VCc revealed important synergies in the perceptions of the goals of the project. The cooperation among partners resulted in major opportunities for each participant, assuring the achievement of the declared aims and the fulfillment of benefits for each partner.

More specifically, the overlapping areas (Figure 7) within the above-mentioned approaches reveal the main objects of cooperation (activities and goals); more precisely: 


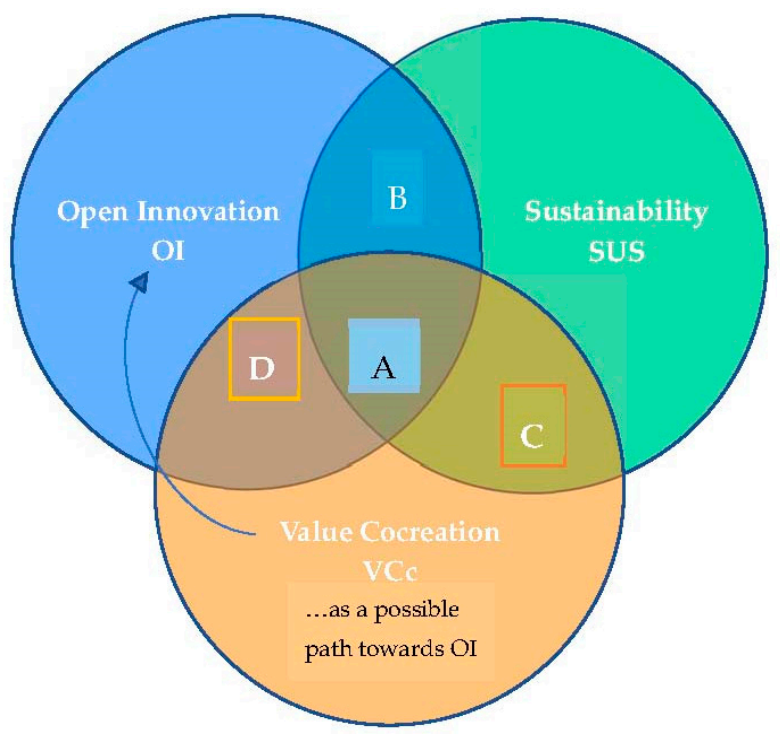

Figure 7. The synergistic interactions in the framework and overlapping areas. (A) (SUS-VCc-OI) Cooperation by each part involved in the network on innovation process to pursue economic and environmental goals; (B) (OI/SUS) sharing knowledge to innovate the fish vessel toward sustainability; (C) (SUS-VCc) value co-creation in a pluridimensional perspective pursuing innovation and social benefits (more efficiency, less environmental impact both in production and in consumer phases, easier access to public subsidies, and users' satisfaction); (D) (OI-VCs) stakeholder engagement (fishermen, research center, university, and SMEs) and cooperation among partners to meet users' expectations. Also, considering both theoretical point of view (see Figures 1 and 2) and the results, the VCc can be seen as a possible path towards OI.

Starting from the results of the case study, it was observed that in the context of the OI value network established for an innovative and sustainable purpose, VCc was realized. Sustainability of the outcome project corresponds to the purpose of the triple bottom line paradigm, as it implies environmental (environmental protection), social (growing awareness of environmental protection), and economic (implications for the production of vessels with low environmental impact, and efficiency and effectiveness of on-board equipment) effects.

From the case study, it emerges that the relations between people involved in the project enhanced the stakeholders' engagement, and from this the value propositions emerged. These last ones are considered, in this context, as minor business changes [129] derived in the TESEO I project from a constant sharing of knowledge and experience between each actor of this value network. As stated, the value propositions are part of co-creation process and in every phase of the project all the solutions provided to fix specific problems have contributed to the total process of value co-creation.

Sustainability of the outcome of the TESEO I project corresponds to the purpose of the triple bottom line paradigm [17], as it implies environmental (environmental protection), social (growing awareness of environmental protection), and economic (implications for the production of vessels with low environmental impact, and efficiency and effectiveness of on-board equipment) effects. The core concept of sustainability in the TESEO I project scope has stimulated the collaboration and dialogue in solving problems mainly related to the preservation of the environment and the well-being of human resources, who are direct users of the product.

\section{Conclusions}

The theoretical framework built on sustainability (SUS), open innovation (OI), and value cocreation $(\mathrm{VCc})$ constitutes a unique framework that is not found in current literature. The synergistic interactions of these three paradigms allow for possible future research to be framed in confirmatory 
case studies. This case study highlights the validity of the theoretical framework, demonstrating how OI and VCc can be directed towards the creation of a new product designed and built with high sustainability criteria. The interactions between multiple actors and relationship management led to better engagement that, in the TESEO project, facilitated the creation of value propositions and, starting from this, the co-creation of value.

The theoretical implications for this study are the theoretical framework proposed, which, however, needs further research to generalize its applicability. One of the research avenues can be the deconstruction of each paradigm of the framework in order to define specific variables and indicators and investigate the possible relations between them.

The practical implications are represented in the opportunity for those organizations that intend to establish a network and can manage an innovative project through sustainability to co-create value. Concretely, in this type of network the relationships have a win-win nature, and the knowledge sharing among the actors' pursuit of value facilitation (as part of the total process of co-creation) and reduced project risk aims to maximize value co-creation. The main impact in adopting this framework is the awareness of the potential of the values in uses that are obtainable from the "collaborative process of cocreation between parties" [130] (p. 256).

Through the framework and this case study it is also possible to adopt a method to reduce the risk of project failure, capturing the potential of stakeholder engagement to maximize the emergence of value propositions to co-create value through sustainability.

The main limitation of this study is the non-generalizability of the results, also considering that the "generalizability is not a characteristic of the results of a study, but a characteristic of the theory, which needs to be achieved through replications" [131] (p. 9). This is for two main reasons: Firstly, the methodology adopted in this work is a single case study and is not sufficient for generalization; Secondly, the context of the case study is a network that is established to access public funds to realize an innovative product.

Starting from these points, further research can be oriented in two ways: firstly, by replicating the conditions to realize a multiple case study with another project for confirmatory analyses; secondly, by investigating the possibility of applying this framework not only in the context of projects.

Acknowledgments: The authors are grateful to all the interviewed for their essential guidance, suggestions, and support towards the final outcome of this work.

Author Contributions: Although the paper is the result of a synergic work, Sections 1, 3.1 and 4 are attributed to Daniela Rupo; Sections 2 and 2.1, Sections 2.2-2.4 to Mirko Perano; Sections 3, 3.2 and 3.3 to Giovanna Centorrino; Section 5 to Alfonso Vargas-Sanchez.

Conflicts of Interest: The authors declare no conflict of interest.

\section{Appendix A}

\section{Appendix A.1}

Interview Protocol (For the Scientific Director and for the Chief Engineer)

1. Can you please give us a brief description of the aim and the more relevant activities of the project?

2. What are the main benefits for the overall project that are expected from the collaboration among partners?

3. Which kind of benefit do you feel has been more relevant for each partner?

4. What are the main problems faced during the collaboration?

5. How the partners of the project develop cooperation with regard to innovation?

6. To what extent have sustainability issues been assumed in the design process?

7. Which kinds of implications were deemed as strategic features in the development of innovative solutions through the network?

8. What factors could hinder future collaborations with the partners? 
9. Which aspects of the cooperation turned out to be more complex and needed more coordination?

10. Which contributions by each partner involved in the project do you consider to be more relevant?

11. Do you plan to engage in similar collaboration projects in the future?

12. How have the innovative solutions of the project been identified?

13. For the purposes of energy saving, have alternative solutions been assessed?

14. Do you think that the same model of the network in the innovation process could be usefully replicated in another context?

Appendix A.2

Interview Protocol (For Some Representatives of Fisher Association)

1. Can you please give us a brief description of your activity?

2. Which types of fishing have you carried out?

3. Usually how long do you spend on board for your fishing?

4. What are the main issues that may be identified in the type of vessel that is used routinely?

5. Does the space intended for rest fit your needs?

6. Is the space for board activities functional for the specific requirements of the fisheries?

7. To what extent does the environment have to be considered in the innovation process?

8. Do you feel the safe on board when properly secured?

9. Did you feel like you were an integral part of the project when you made the TESEO I vessel?

\section{References}

1. PONREC. Italian National Operative Program for Research and Competitiveness 2007-2013. Available online: http:/ / www.ponrec.it/ (accessed on 12 December 2017).

2. Lush, R.F.; Vargo, S.L. Service-Dominant logic as a Foundation for a General Theory. In The Service-Dominant Logic of Marketing. Dialog, Debate, and Directions; Lusch, R.F., Vargo, S.L., Eds.; M.E. Sharpe: Armonk, NY, USA; London, UK, 2006; pp. 406-420, ISBN 978-07-6561-491-9.

3. Pellicano, M.; Perano, M.; Casali, G.L. The Enterprise Relational View. Exploring future in strategic management. In Business Systems B.S.LAB E-Book Series, Proceedings of the 4th Business Systems Laboratory International Symposium "Governing Business Systems", Mykolas Romeris University, Vilnius, Lithuania, 24-26 August 2016; Caputo, F., Ed.; AMAZON: Avellino, Italy, 2016; ISBN 978-88-9082-423-4.

4. Pellicano, M. L'Impresa Relazionale; Giappichelli: Turin, Italy, 2017; ISBN 978-88-9216-601-1.

5. Perano, M.; Cerrato, R. Il Bilancio Sociale tra Pianificazione Strategica e Co-Creazione di Valore; Giappichelli: Turin, Italy, 2017; ISBN 978-88-9211-129-5.

6. Ciasullo, V.M.; Troisi, O. La Visione Relazionale dell'Impresa; Giappichelli: Turin, Italy, 2017; ISBN 978-88-921-6692-9.

7. Vargo, S.L.; Maglio, P.P.; Akaka, M.A. On value and value co-creation: A service systems and service logic perspective. Eur. Manag. J. 2008, 26, 145-152. [CrossRef]

8. Lusch, R.F.; Vargo, S.L.; Tanniru, M. Service, value networks and learning. J. Acad. Mark. Sci. 2010, 38, 19-31. [CrossRef]

9. Allen, T.J.; Cohen, W.M. Information flow in research and development laboratories. Adm. Sci. Q. 1969, 14, 12-19. [CrossRef]

10. Tilton, J.E. International Diffusion of Technology: The Case of Semiconductors; The Brookings Institute: Washington, DC, USA, 1971; ISBN 978-08-1578-458-6.

11. Allen, T.J. Managing the Flow of Technology; MIT Press: Cambridge, MA, USA, 1977; ISBN 978-02-6201-048-1.

12. Cohen, W.; Levinthal, D. Innovation and Learning: The two faces of R\&D. Econ. J. 1989, 99, 569-596.

13. Chesbrough, H.W. Open Innovation: The New Imperative for Creating and Profiting from Technology; Harvard Business School Press: Boston, MA, USA, 2003; ISBN 978-15-7851-837-1.

14. Dahlander, L.; Gann, D.M. How open is innovation? Res. Policy 2010, 39, 699-709. [CrossRef] 
15. Aquilani, B.; Abbate, T. Co-creation and Open Innovation: Bridging the two paradigms. In Proceedings of the R\&D Management Conference 2016 Titled from Science to Society: Innovation and Value Creation, Cambridge, UK, 3-6 July 2016.

16. UN. Transforming Our World: The 2030 Agenda for Sustainable Development. 2015. Available online: https:/ / sustainabledevelopment.un.org/post2015/transformingourworld (accessed on 17 February 2018).

17. Elkington, J. Cannibals with Forks-The Triple Bottom Line of 21st Century Business; Capstone Publishing Ltd.: Oxford, UK, 1999; ISBN 978-1-841-12084-3.

18. European Environment Agency. Greenhouse Gas Emission Trends. 2017. Available online: https:/ /www.eea. europa.eu/data-and-maps/indicators/greenhouse-gas-emission-trends (accessed on 25 November 2018).

19. European Commission. Blue Growth Opportunities for Marine and Maritime Sustainable Growth, Doc nr. COM(2012) 494 Final. 2012. Available online: http://eur-lex.europa.eu/legal-content/EN/TXT/PDF/?uri= CELEX:52012DC0494\&from=EN (accessed on 25 November 2018).

20. Yin, R.K. Case Study Research: Design and Methods, 4th ed.; Sage: Thousand Oaks, CA, USA, 2009; ISBN 978-1-412-96099-1.

21. Piller, F.; West, J. Firms, Users, and Innovation: An Interactive Model of Coupled Open Innovation. In New Frontiers in Open Innovation; Chesbrough, H., Vanhaverbeke, W., West, J., Eds.; Oxford University Press: Oxford, UK, 2014; ISBN 978-0199682461.

22. Vargo, S.L.; Lusch, R.F. Evolving to a new dominant logic for marketing. J. Mark. 2004, 68, 1-17. [CrossRef]

23. Vargo, S.L.; Lusch, R.F. Service-dominant logic: Continuing the evolution. J. Acad. Mark. Sci. 2008, 36, 1-10. [CrossRef]

24. Smith, P.G.; Reinertsen, D.G. Developing Products in Half the Time; Van Nostrand Reinhold: New York, NY, USA, 1991.

25. Jongbae, K.; Wilemon, D. Focusing the fuzzy front-end in new product development. RED Manag. 2002, 32, 269-279.

26. Koen, P.; Ajamian, G.; Burkart, R.; Clamen, A.; Davidson, J.; Elkins, C.; Herald, K.; Incorvia, M.; Johnson, A.; Karol, R.; et al. Providing clarity and a common language to the "Fuzzy Front End". Res. Technol. Manag. 2001, 2, 46-55. [CrossRef]

27. Teddlie, C.; Tashakkori, A. Major Issue and Controversies in the Use of Mixed Methods in the Social and Behavioral Science. In Handbook of Mixed Methods in Social \& Behavioral Research; Tashakkori, A., Teddlie, C., Eds.; Sage Publications, Inc.: Thousand Oaks, CA, USA, 2003; ISBN 9781412972666.

28. Kuhn, T.S. The Structure of Scientific Revolutions; University of Chicago Press: Chicago, IL, USA, 1962.

29. Corbetta, P. Metodologie e Tecniche Della Ricerca Sociale; Il Mulino: Bologna, Italy, 1999; ISBN 88-15-06792-2.

30. World Commission on Environment and Development. Our Common Future; Oxford University Press: Melbourne, Australia, 1987; ISBN 978-0192820808.

31. Robinson, J. Squaring the circle? Some thoughts on the idea of sustainable development. Ecol. Econ. 2004, 48, 369-384. [CrossRef]

32. Belz, F.M. Shaping the future: Sustainable innovation and entrepreneurship. Soc. Bus. 2013, 3, 311-324. [CrossRef]

33. Hall, J.; Daneke, G.; Lenox, M. Sustainable development and entrepreneurship: Past contributions and future directions. J. Bus. Ventur. 2010, 25, 439-448. [CrossRef]

34. Belz, F.M.; Binder, J.K. Sustainable Entrepreneurship: A Convergent Process Model. Bus. Strategy Environ. 2017, 26, 1-17. [CrossRef]

35. Jensen, M.C.; Meckling, W.H. The nature of man. J. Appl. Corp. Financ. 1994, 7, 4-19. [CrossRef]

36. Cohen, B.; Smith, B.; Mitchell, R. Toward a Sustainable Conceptualization of Dependent Variables in Entrepreneurship Research. Bus. Strat. Environ. 2008, 17, 107-119. [CrossRef]

37. Salomone, R.; Rupo, D.; Saija, G. Innovative environmental management tools for the agri-food chain. In Product-Oriented Environmental Management System (POEMS)_Improving Sustainability and Competitiveness in the Agri-Food Chain with Innovative Environmental Management Tools; Salomone, R., Clasadonte, M.T., Proto, M., Raggi, A., Eds.; Springer: Dordrecht, The Netherlands, 2013; pp. 3-25.

38. Elkington, J. Towards the sustainable corporation: Win-win-win business strategies for sustainable development. Calif. Man. Rev. 1992, 2, 90-100. [CrossRef]

39. Schaltegger, S.; Wagner, M. Sustainable entrepreneurship and sustainability innovation: Categories and interactions. Bus. Strategy Environ. 2011, 20, 222-237. [CrossRef] 
40. Thompson, N.; Kiefer, K.; York, J.G. Distinctions not dichotomies: Exploring social, sustainable, and environmental entrepreneurship. In Social and Sustainable Entrepreneurship; Lumpkin, G.T., Katz, J.A., Eds.; Advances in Entrepreneurship, Firm Emergence and Growth; Emerald Group Publishing Limited: Bingley, UK, 2011; pp. 201-229, ISBN 978-1-78052-072-8.

41. Centorrino, G. Emissions Trading in Financial Statements: New Italian Accounting Standards. Online J. Sci. Technol. 2014, 4, 48-55.

42. McWilliams, A.; Siegel, D. Corporate social responsibility and financial performance: Correlation or misspecification? SMJ 2000, 21, 603-609. [CrossRef]

43. Hull, C.E.; Rothenberg, S. Firm performance: The interactions of corporate social performance with innovation and industry differentiation. SMJ 2008, 29, 781-789. [CrossRef]

44. Schumpeter, J.A. The Theory of Economic Development: An Inquiry into Profits, Capital, Credit, Interest and the Business Cycle, Opie R (trans); Harvard University Press: Cambridge, MA, USA, 1934.

45. Peters, T. Get innovative or get dead (Part I). Calif. Manag. Rev. 1990, 33, 9-26. [CrossRef]

46. Peters, T. Get innovative or get dead (Part II). Calif. Manag. Rev. 1991, 33, 9-23. [CrossRef]

47. Clark, K.B.; Fujimoto, T. Product Development Performance; Harvard Business School Press: Boston, MA, USA, 1991.

48. Hamel, G.; Prahalad, C.K. Competing for the Future; Harvard Business School Press: Boston, MA, USA, 1994.

49. Brown, S.L.; Eisenhardt, K.M. Product development: Past research, present findings, and future directions. Acad. Manag. Rev. 1995, 20, 343-378.

50. Zahra, S.A.; Covin, J.G. Contextual influences on the corporate entrepreneurship-performance relationship: A longitudinal analysis. J. Bus. Ventur. 1995, 10, 43-58. [CrossRef]

51. Christensen, C.M.; Bower, J.L. Customer power, strategic investment, and the failure of leading firms. SMJ 1996, 17, 197-218. [CrossRef]

52. Teece, D.J.; Pisano, G.; Shuen, A. Dynamic capabilities and strategic management. SMJ 1997, 18, 509-533. [CrossRef]

53. Covin, J.G.; Miles, M.P. Corporate entrepreneurship and the pursuit of competitive advantage. Entrep. Theory Pract. 1999, 23, 47-63. [CrossRef]

54. O'Reilly, C.A.; Tushman, M.L. The ambidextrous organization. Harv. Bus. Rev. 2004, 82, 74-81. [PubMed]

55. Shilling, M.E. Strategic Management of Technological Innovation, 2nd ed.; McGraw-Hill: Irwin, NY, USA, 2006; ISBN 978-007321058-2.

56. McGrath, R.G.; Tsai, M.H.; Venkataraman, S.; MacMillan, I.C. Innovation, Competitive Advantage and Rent: A Model and Test. Manag. Sci. 1996, 42, 389-403. [CrossRef]

57. Smith, A.; Voß, J.P.; Grin, J. Innovation studies and sustainability transitions: The allure of the multi-level perspective and its challenges. Res. Policy 2010, 39, 435-448. [CrossRef]

58. Leifer, R.; McDermott, C.; O'Connor, G.; Peters, L.; Rice, M.; Veryzer, R. Radical Innovation: How Mature Companies Can Outsmart Upstarts; Harvard Business School Press: Brighton, MA, USA, 2000; ISBN 978-0875849034.

59. Henderson, R.M.; Clark, K.B. The Reconfiguration of Existing Product Technologies and the Failure of Established Firms. Adm. Sci. Q. 1990, 35, 9-30. [CrossRef]

60. Dewar, R.D.; Dutton, J.E. The adoption of radical and incremental innovations: An empirical analysis. Manag. Sci. 1986, 32, 1422-1433. [CrossRef]

61. March, J.G. Exploration and Exploitation in Organizational Learning. Organ. Sci. 1991, 2, 71-87. [CrossRef]

62. Freeman, R.E. Networks of Innovators. Res. Policy 1991, 20, 499-514. [CrossRef]

63. Hargadon, A.B.; Sutton, R.I. Technology Brokering and Innovation. Adm. Sci. Q. 1997, 42, 157-166. [CrossRef]

64. Ahuja, G.; Lampert, C.M. Entrepreneurship in the Large Corporation: A Longitudinal Study of How Established Firms Create Breakthrough Inventions. SMJ 2001, 22, 521-543. [CrossRef]

65. Huizingh, E.K.R.E. Open innovation: State of the art and future perspectives. Technovation 2010, 31, 2-9. [CrossRef]

66. Gassmann, O. Opening up the innovation process: Towards an agenda. RED Manag. 2006, 36, $223-226$.

67. Chesbrough, H.W.; Vanhaverbeke, W.; West, J. (Eds.) Open Innovation: Researching a New Paradigm; Oxford University Press: London, UK, 2008; ISBN 978-0199226467.

68. Vanhaverbeke, W.; Du, J. Reframing the role of lead users in radical innovations: An open innovation perspective. Int. J. Bus. Environ. 2010, 3, 202-220. [CrossRef] 
69. Chesbrough, H.; Bogers, M. Explicating Open Innovation. Clarifying an emerging paradigm for understanding innovation. In New Frontiers in Open Innovation; Chesbrough, H., Vanhaverbeke, W., West, J., Eds.; Oxford University Press: Oxford, UK, 2014.

70. Blazevic, V.; Lievens, A. Managing innovation through customer coproduced knowledge in electronic services: An exploratory study. J. Acad. Mark. Sci. 2008, 36, 138-151. [CrossRef]

71. Von Hippel, E. The Sources of Innovation; Oxford University Press: New York, NY, USA, 1988.

72. Lundvall, B.A. (Ed.) National Systems of Innovation: Towards a Theory of Innovation and Interactive Learning; Pinter: London, UK, 1992.

73. Szulanski, G. Exploiting internal stickiness: Impediments to the transfer of best practice. SMJ 1996, 17, $27-43$.

74. Laursen, K.; Salter, A. Open for Innovation: The Role of Openness in Explaining Innovation Performance among UK Manufacturing Firms. SMJ 2006, 27, 131-150. [CrossRef]

75. Freeman, C.; Soete, L. The Economics of Industrial Innovation, 3rd ed.; MIT Press: Cambridge, MA, USA, 1997; ISBN 978-0262561136.

76. Hoffman, K.; Parejo, M.; Bessant, J.; Perren, L. Small firms, R\&D, technology and innovation in the UK: A literature review. Technovation 1998, 18, 39-55.

77. Baum, J.A.C.; Calabrese, T.; Silverman, B.S. Don't go it alone: Alliance network composition and startups' performance in Canadian biotechnology. SMJ 2000, 21, 267-294. [CrossRef]

78. Darby, M.R.; Zucker, L.G.; Wang, A. Universities, Joint Ventures, and Success in the Advanced Technology Program. Contemp. Econ. Policy 2004, 22, 145-161. [CrossRef]

79. Knudsen, M.P.; Mortensen, T.B. Some Immediate-but Negative-Effects of Openness on Product Development Performance. Technovation 2011, 31, 54-64. [CrossRef]

80. Gassmann, O.; Enkel, E. Towards a Theory of Open Innovation: Three Core Process Archetypes. In Proceedings of the R\&D Management Conference (RADMA), ITEM-Institute of Technology Management with Transfer Center for Technology Management (TECTEM), Lisbon, Portugal, 7-9 July 2004.

81. Enkel, E.; Gassmann, O.; Chesbrough, H.W. Open R\&D and open innovation: Exploring the phenomenon. RED Manag. 2009, 39, 311-316.

82. Granstrand, O. The economics and management of technology trade. Int. J. Technol. Manag. 2004, 27, $209-240$. [CrossRef]

83. Chesbrough, H.; Crowther, A.K. Beyond high tech: Early adopters of open innovation in other industries. RED Manag. 2006, 36, 229-236.

84. Fosfuri, A. The Licensing Dilemma: Understanding the Determinants of the Rate of Technology Licensing. SMJ 2006, 27, 1141-1158.

85. Van de Vrande, V.; de Jong, J.P.J.; Vanhaverbeke, W.; de Rochemontd, M. Open innovation in SMEs: Trends, motives and management challenges. Technovation 2009, 29, 423-437. [CrossRef]

86. Cheng, C.; Huizingh, E. Open innovation to increase innovation performance: Evidence from a large survey. In Proceedings of the XXI ISPIM Conference, Bilbao, Spain, 6-9 June 2010.

87. Bianchi, M.; Cavaliere, A.; Chiaroni, D.; Frattini, F.; Chiesa, V. Organisational modes for Open innovation in the bio-pharmaceutical industry: An exploratory analysis. Technovation 2011, 31, 22-33. [CrossRef]

88. Chiaroni, D.; Chiesa, V.; Frattini, F. The Open Innovation Journey: How firms dynamically implement the emerging innovation management paradigm. Technovation 2011, 31, 34-43. [CrossRef]

89. Spohrer, J.; Maglio, P.P.; Bailey, J.; Gruhl, D. Steps toward a science of service systems. Computer 2007, 40, 71-77. [CrossRef]

90. Spohrer, J.; Vargo, S.L.; Caswell, N.; Maglio, P.P. The service system is the basic abstraction of service science. In Proceedings of the 41st Annual Hawaii International Conference on System Science, Waikoloa, HI, USA, 7-10 January 2008.

91. Grönroos, C.; Gummerus, J. The service revolution and its marketing implications: Service logic vs service-dominant logic. Manag. Serv. Qual. 2014, 24, 206-229. [CrossRef]

92. Prahalad, C.K.; Ramaswamy, V. Co-creation Experiences: The Next Practice in Value Creation. J. Interact. Mark. 2004, 18, 5-14. [CrossRef]

93. Ramaswamy, V.; Ozcan, K. The co-Creation Paradigm; Stanford University Press: Stanford, CA, USA, 2014; ISBN 9780804789158.

94. Durugbo, C.; Pawar, K. A unified model of the co-creation process. Expert Syst. Appl. 2014, 41, 4373-4387. [CrossRef] 
95. Maglio, P.P.; Vargo, S.L.; Caswell, N.; Spohrer, J. The service system is the basic abstraction of service science. Inf. Syst. E-Bus. Manag. 2009, 7, 395-406. [CrossRef]

96. Vargo, S.L. Paradigms, Pluralism, and Peripheries: On the Assessment of the S-D Logic. Australas. Mark. J. 2007, 15, 105-108. [CrossRef]

97. Vargo, S.L.; Lush, R.F. Service-dominant logic 2025. Int. J. Res. Mark. 2017, 34, 46-67. [CrossRef]

98. Romero, D.; Molina, A. Collaborative Networked Organisations and Customer Communities: Value Co-Creation and Co-Innovation in the Networking Era. J. Prod. Plan. Control 2011, 22, 447-472. [CrossRef]

99. Vargo, S.L.; Lusch, R. Institutions and axioms: An extension and update of service-dominant logic. J. Acad. Mark. Sci. 2016, 44, 5-23. [CrossRef]

100. PMI. A Guide to the Project Management Body of Knowledge: (PMBOK ${ }^{\circledR}$ Guide), 5th ed.; PMI: Newtown Square, PA, USA, 2013; ISBN 9781935589679.

101. Kerzner, H. Project Management: A Systems Approach to Planning, Scheduling, and Controlling; Wiley: Hoboken, NJ, USA, 2017; ISBN 978-1-118-02227-6.

102. Maglio, P.P.; Spohrer, J. Fundamentals of service science. J. Acad. Mark. Sci. 2008, 36, 18-20. [CrossRef]

103. Chesbrough, H.W.; Appleyard, M.M. Open Innovation and Strategy. Calif. Manag. Rev. 2007, 50, 57-76. [CrossRef]

104. Lopes, C.M.; Scavarda, A.; Hofmeister, L.F.; Tavares Thomé, A.M.; Roehe Vaccaro, G.L. An analysis of the interplay between organizational sustainability, knowledge management, and open innovation. J. Clean. Prod. 2017, 142, 476-488. [CrossRef]

105. Rossi, A.; Dvortsin, L.; Malandrin, V. The co-production of sustainability by learning networks. The case of reconstruction of knowledge and practices around bread production. In Proceedings of the Farming Systems Facing Global Challenges: Capacities and Strategies-11th European IFSA Symposium, Berlin, Germany, 1-4 April 2014; Aenis, T., Knierim, A., Riecher, M.C., Ridder, R., Schobert, H., Fischer, H., Eds.; International Farming Systems Association (IFSA) Europe: Vienna, Austria, 2016; pp. 1398-1409.

106. Hansen, E.G.; Grosse-Dunker, F. Sustainability-Oriented Innovation (December 19, 2012). In Encyclopedia of Corporate Social Responsibility; Idowu, S.O., Capaldi, N., Zu, L., Das Gupta, A., Eds.; Springer: Berlin/Heidelberg, Germany, 2013. [CrossRef]

107. Stake, R.E. The Art of Case Study Research; Sage Publications: Thousand Oaks, CA, USA, 1995; ISBN 9780803957671.

108. Eisenhardt, K.M.; Graebner, M.E. Theory building from cases: Opportunities and challenges. Acad. Manag. J. 2007, 50, 25-32. [CrossRef]

109. Denzin, N.K. The Research Act: A Theoretical Orientation to Sociological Methods; McGraw-Hill: New York, NY, USA, 1978.

110. Bowen, G.A. Document Analysis as a Qualitative Research Method. Qual. Res. J. 2009, 9, 27-40. [CrossRef]

111. Noor, K.B.M. Case Study: A Strategic Research Methodology. Am. J. Appl. Sci. 2008, 5, 1602-1604. [CrossRef]

112. Deshpandé, R.; Farley, J.U. Organizational culture, market orientation, innovativeness, and firm performance: An international research odyssey. Int. J. Res. Mark. 2004, 21, 3-22. [CrossRef]

113. Casali, G.L.; Perano, M.; Moretta Tartaglione, A.; Zolin, R. How Business Idea Fit Affects Sustainability and Creates Opportunities for Value Co-Creation in Nascent Firms. Sustainability 2018, 10, 189. Available online: http:/ / www.mdpi.com/2071-1050/10/1/189 (accessed on 19 February 2018). [CrossRef]

114. Lee, T.W. Using Qualitative Methods in Organizational Research; Sage Publications: Thousand Oaks, CA, USA, 1999; ISBN 0-7619-0806-4.

115. Gibbert, M.; Ruigrok, W.; Wicki, B. What passes as a rigorous case study? SMJ 2008, 29, 1465-1474. [CrossRef]

116. Zúñiga-Vicente, J.Á.; Borrego, C.A.; Forcadell, F.J.; Galán José, I. Assessing the effect of public subsidies on firm R\&D investment: A survey. J. Econ. Surv. 2014, 28, 36-67.

117. Greco, M.; Grimaldi, M.; Cricelli, L. Hitting the nail on the head: Exploring the relationship between public subsidies and open innovation efficiency. Technol. Forecast. Soc. Chang. 2017, 118, 213-225. [CrossRef]

118. Hokamuro, H.; Nishimura, J. Not just financial support? Another role of public subsidy in university-industry research collaborations. Econ. Innov. New Technol. 2014, 24, 633-659. [CrossRef]

119. Segarra-Blasco, A.; Arauzo-Carod, J.M. Sources of innovation and industry-university interaction: Evidence from Spanish firms. Res. Policy 2008, 37, 1283-1295. [CrossRef] 
120. European Union, Directive 2008/56/EC of the European Parliament and of the Council of 17 June 2008 Establishing a Framework for Community Action in the Field of Marine Environmental Policy. Available online: http:/ / eur-lex.europa.eu/LexUriServ/LexUriServ.do?uri=OJ:L:2008:164:0019:0040:EN: PDF (accessed on 15 January 2018).

121. Van de Vrande, V.; Lemmens, C.; Vanhaverbeke, W. Choosing governance modes for external technology sourcing. RED Manag. 2006, 36, 347-363.

122. Lanzarotti, V.; Manzini, R. Different modes of open innovation: A theoretical framework and an empirical study. Int. J. Innov. Manag. 2009, 13, 615-636. [CrossRef]

123. Berger, C.; Möslein, K.M.; Piller, F.T.; Reichwald, R. Co-Designing Modes of Cooperation at the Customer Interface: Learning from Exploratory Research. Eur. Manag. Rev. 2005, 2, 70-87. [CrossRef]

124. Michelino, F.; Lamberti, E.; Cammarano, A.; Caputo, M. Measuring Open Innovation in the Bio-Pharmaceutical Industry. Creativity Innov. Manag. 2015, 24, 4-28. [CrossRef]

125. Emden, Z.; Calantone, R.J.; Droge, C. Collaborating for New Product Development: Selecting the Partner with the Maximum Potential to Create Value. J. Prod. Innov. Manag. 2006, 23, 330-341. [CrossRef]

126. Ramaswamy, V.; Gouillart, F. The Power of Co-Creation: Build It with Them to Boost Growth, Productivity, and Profits; Free Press: New York, NY, USA, 2010; ISBN 978-1439181041.

127. Ramaswamy, V. Co-creation of value-Towards an expanded paradigm of value creation. Mark. Rev. St. Gallen 2009, 26, 11-17. [CrossRef]

128. Mazzola, E.; Bruccoleri, M.; Perrone, G. The Effect of Inbound, Outbound and Coupled Innovation on Performance. Int. J. Innov. Manag. 2012, 16, 1-27. [CrossRef]

129. Nair, S.; Paulose, H.; Palacios, M.; Tafur, J. Service orientation: Effectuating business model innovation. Serv. Ind. J. 2013, 33, 958-975. [CrossRef]

130. Vargo, S.L.; Lusch, R. From goods to service(s): Divergences and convergences of logics. Ind. Mark. Manag. 2008, 37, 254-259. [CrossRef]

131. Dul, J.; Hak, T. Case Study Methodology in Business Research; Butterworth-Heinemann-Elsevier: Burlington, MA, USA, 2008; ISBN 978-0-7506-8196-4.

(C) 2018 by the authors. Licensee MDPI, Basel, Switzerland. This article is an open access article distributed under the terms and conditions of the Creative Commons Attribution (CC BY) license (http://creativecommons.org/licenses/by/4.0/). 